Article

\title{
Fatty Acids from Hermetia illucens Larvae Fat Inhibit the Proliferation and Growth of Actual Phytopathogens
}

\author{
Elena Marusich ${ }^{1, *,+}$, Heakal Mohamed ${ }^{1,+}+\left(\mathbb{C}\right.$, Yuriy Afanasev ${ }^{1(D)}$ and Sergey Leonov $1,2, * \mathbb{C}$ \\ 1 School of Biological and Medical Physics, Moscow Institute of Physics and Technology, \\ 141700 Dolgoprudny, Moscow Region, Russia; m.heakal@phystech.edu (H.M.); \\ yurii.afanasev@phystech.edu (Y.A.) \\ 2 Institute of Cell Biophysics of the Russian Academy of Sciences, 142290 Pushchino, Moscow Region, Russia \\ * Correspondence: marusich.ei@mipt.ru (E.M.); leonov.sv@mipt.ru (S.L.); Tel.: +7-965-247-1982 (E.M.); \\ +7-915-055-5643 (S.L.) \\ + These authors contributed equally to this work.
}

Received: 8 August 2020; Accepted: 14 September 2020; Published: 16 September 2020

check for updates

\begin{abstract}
The rapid increase of plant diseases caused by bacterial phytopathogens calls for an urgent search for new antibacterials. Antimicrobial compounds of natural origin stand up as frontiers in the attempts of the antibiotic overuse replacement. With this in mind, the Hermetia illucens (H. illucens) larvae have recently gained attention as a promising approach to fulfill this need. This study aimed to isolate the active constituents of H. illucens larvae fat and to estimate its antimicrobial capacity. We discovered the best composition of extracting solution retaining the pronounced antimicrobial activity of the extract. Using gas chromatography-mass spectrometry (GC-MS), we identified the unique natural array of fatty acids as the major constituents of the acidified water-methanol extract (AWME) as having new antimicrobial potency. In standard turbidimetric assay, the minimum inhibitory concentration (MIC) of the AWME was $0.78 \mathrm{mg} / \mathrm{mL}$ after $24 \mathrm{~h}$ of incubation for all five tested phytopathogenic bacteria strains: Pantoea agglomerans, Xanthomonas campestris, Pectobacterium carotovorum subsp. carotovorum, Pectobacterium atrosepticum, and Dickeya solani. The minimum bactericidal concentration (MBC) ranged from 0.78 to $1.56 \mathrm{mg} / \mathrm{mL}$ against all tested strains after $24 \mathrm{~h}$ of incubation. The inhibition zone size of AWME (INZ) at $50 \mathrm{mg} / \mathrm{mL}$ concentration was in the range $12.2 \pm 0.56$ to $19.0 \pm 0.28 \mathrm{~mm}$, while zone size for the positive control (penicillin-streptomycin) ( $5000 \mathrm{IU} / \mathrm{mL}-5000 \mu \mathrm{g} / \mathrm{mL}$ ) was in the scale of $20.63 \pm 0.53$ to $24.0 \pm 0.35 \mathrm{~mm}$ as revealed by standard disk diffusion assay. For the first time, our findings indicated the substantial antibacterial potential of AWME of $H$. illucens larvae fat against these actual phytopathogens, thus paving the way for further research to determine the mechanism of action in crop protection.
\end{abstract}

Keywords: black soldier fly; fatty acids; larvae extract; phytopathogenic bacteria; antibacterial activity

\section{Introduction}

Bacterial phytopathogens are among the most important causal agents of plant diseases, with a negatively increased economic impact on crop production. Phytopathogens affect all food-producing plants colonizing either their surface or tissues [1]. They cause symptoms such as spots, blights, cankers, tissue rots, and/or hormone imbalances that lead to the plant overgrowth, stunting, root branching, and leaf epinasty [1,2]. Bacterial soft rot caused by pectinolytic Pectobacterium species (soft rot Pectobacteriaceae) and Dickeya species (Solanum tuberosum) is one of the major disease of the potato production in many potato-growing regions of the world [3,4]. High genotypic and phenotypic diversity of these bacteria caused disease symptoms on a wide range of host plants. Pectobacterium induce tissue maceration or rot symptoms in plants. These pathologies caused by the phytopathogen 
production of extracellular enzymes degrade cell wall constituents, such as pectate lyases and other pectinases, cellulases, and proteases [5,6]. Xanthomonas belongs to gram-negative bacteria that can infect such crops as beans, rice, citrus, and cotton [7]. Xanthomonas campestris pv campestris invades the vascular system or the mesophylls and cause black rot diseases for cruciferous crops such as mustard, cabbage, broccoli, cauliflower, brussels sprouts, and radish worldwide [8]. Dickea solani and Pantoea agglomerans distribute among various broad of host range, many crops ranging from potato to banana, fire blight disease of ornamentals, fruit trees, bushes, the soft rot diseases, and others [9].

However, the control of diseases caused by the pathogens listed above is difficult due to the limited efficacy of existed biological or chemical agents and the resistance to antibiotics long-term overuse [10]. The combination of some reliable methods was applied to control plant diseases, including mechanical (such as hot water, steam, dry hot air, solar) or UV irradiation treatment, and chemical processing by antibiotics, natural bactericides, or synthetic anti-microbial peptides [10,11]. It is worth stressing that, at present, there are no methods enable to eradicate post-infection besides the only preventive measures, which are commonly applied to limit or eliminate their further prevalence. Persistent infection increases the levels of morbidity and mortality globally and are an essential cause of plants' recurrent infective diseases. This might also be a prime reason for the crop disease outbreaks and recurrence, even with the frequent use of antimicrobial compounds and other management methods in the field $[12,13]$. Antimicrobial compounds of natural origin stand up as frontiers in the attempts of the overused antibiotics replacement.

In this study, we used the black soldier fly H. illucens (BSFL) as a primary source to isolate compounds from their larvae fat with the antimicrobial capacity. Compared with other insects, BSFL does not accumulate pesticides or mycotoxins and have higher saturated fat content, suggesting a safe and economic prospect [14]. The BSFL demonstrated a high grade of balance between saturated and unsaturated fatty acids (FAs) with pronounced antiviral, antibacterial, and antiprotozoal activities [15]. Most antibacterial activities of BSFL larvae attributed to soluble peptide fractions isolated by acidic treatment of the whole body of larvae (WBL) [16]. The methanol extract of WBL of L. cuprina demonstrated the in vitro antibacterial activity of this extract against seven selected human wound pathogens (Staphylococcus aureus, methicillin-resistant S. aureus, S. epidermidis, Streptococcus pyogenes, Klebsiella pneumoniae, Pseudomonas aeruginosa, and Escherichia coli). The reconstituted larval extract was highly robust and thermally stable [17]. These observations substantiated the feasibility of the methanol extraction method in the production of larval extract. Nevertheless, so far none of the studies demonstrated the antibacterial activity of BSFL AWME of larvae fat against a wide range of phytopathogenic bacteria.

H. illucens larvae consist of $15 \%$ to $49 \%$ of fat, providing a rich source of lipids [18]. This study aimed to develop a new procedure to constitute the AWME composition via modified acidic water-methanol extraction and to demonstrate in vitro the antibacterial activity of this extract against five crucial plant pathogenic bacteria Xanthomonas campestris subsp. campestris, Pantoea agglomerans, Dickeya solani, Pectobacterium carotovorum subsp. carotovorum, and Pectobacterium atrosepticum. To our knowledge, the H. illucens larvae fat was directly extruded from alive BSFL, never used before as a natural source for this extraction. This study addresses the urgent needs of new antibacterial agents for agriculture crop protection.

\section{Materials and Methods}

\subsection{BSFL Sample, Reagents, and Supply}

Fat was isolated from alive Hermetia illucens larvae of 15 days old by using mechanical pressing machine and provided by the company NordTechSad, LLC (Arkhangelsk, Russia), and used for this study. All experiments were performed with fat from BSFL under sterile condition at room temperature.

Hydrochloric acid $(\mathrm{HCl})$, methanol $\left(\mathrm{CH}_{3} \mathrm{OH}\right)$, carbon tetra chloride $\left(\mathrm{CCl}_{4}\right)$, dimethylformamide (DMFA), hexane $\left(\mathrm{C}_{6} \mathrm{H}_{14}\right)$, dichloromethane $\left(\mathrm{CH}_{2} \mathrm{Cl}_{2}\right)$, dimethyl sulfoxide (DMSO), chloroform 
$\left(\mathrm{CHCl}_{3}\right)$, formaldehyde $\left(\mathrm{CH}_{2} \mathrm{O}\right)$, acetonitrile $\left(\mathrm{CH}_{3} \mathrm{CN}\right)$, and isoamyl alcohol $\left(\mathrm{C}_{5} \mathrm{H}_{11} \mathrm{OH}\right)$ were purchased from Thermo Fisher Scientific, Waltham, MA, USA. Luria-Bertani broth and agar (LB), Mullar Hinton agar (MHA) were purchased from Sigma-Aldrich, St. Louis, MO, USA. Tissue culture 96-well plates (TPP, Trasadingen, Switzerland), 100-X mixture of antibiotics penicillin-streptomycin (5000 U/mL-5000 $\mu \mathrm{g} / \mathrm{mL}$ ) (Gibco, Thermo Fisher Scientific, Waltham, MA, USA), Petri dishes $(90 \mathrm{~mm})$ (Pertin, Saint Petersburg, Russia), paper discs, 6 mm diameter (Himedia, Mumbai, India), sterile swab (Nigbo Greetmed medical instruments CO., LTD., Nigbo, China) were used for this work.

\subsection{Bacterial Strains and Culture Growth}

Antibacterial efficacy of AWME was evaluated against the following bacterial strains: Pantoea agglomerans (Pagg) (ATCC 27995), Xanthomonas campestris (Xcc) (ATCC 13951), Pectobacterium carotovorum subsp. carotovorum (Pbc) (ATCC 15713), Pectobacterium atrosepticum (Pba) (ATCC BAA-672D) and Dickeya solani (Dsol) (NCBI IPO 2222). The bacterial strains used in this study were purchased from the American Type Culture Collection (ATCC), Manassas, USA.

The bacterial strains were stored in glycerol stock $(40 \%, v / v)$ at $-80{ }^{\circ} \mathrm{C}$. To culture, they were incubated overnight in $10.0 \mathrm{~mL}$ of $\mathrm{LB}$ broth at $28 \pm 0.5^{\circ} \mathrm{C}$. The overnight culture was adjusted to the $0.5 \mathrm{OD}_{600}$, equal $0.5 \mathrm{McFarland}\left(1-5 \times 10^{8} \mathrm{CFU} / \mathrm{mL}\right)$. All experiments were performed under aseptic conditions (Safe Fast Elite, Ferrara, Italy).

\subsection{BSFL Fat Extraction}

The BSFL fat extract (AWME) was prepared by treatment of $3 \mathrm{~g}$ of larvae fat with $10 \mathrm{~mL}$ of mixture of water (Milli Q quality), methanol (99.9\%, HPLC grade), and hydrochloric acid (37\%) in the ratio (90:9:1) at $\mathrm{pH}<1$. Briefly, $3 \mathrm{~g}$ of larvae was melted in $10 \mathrm{~mL}$ of extraction solution under hot tap water $\left(52^{\circ} \mathrm{C}\right.$ ) during $5.0 \mathrm{~min}$, then homogenized thoroughly by vortex V-1 (BIOSAN/Latvia) for $10.0 \mathrm{~min}$ and subjected to extraction on the orbital shaker Mixmate Eppendorf AG, Hamburg Germany) at $2000 \mathrm{rpm} / \mathrm{min}$ for $24 \mathrm{~h}$ at room temperature. Next, the mixture was sonicated at $35^{\circ} \mathrm{C}$ for $10.0 \mathrm{~min}$ (Elmasonic S 30H, Singen, Germany), then finally homogenized on ULTRA TURRAX-25 homogenizer (IKA, Deutschland, Germany) at 17,000.0 rpm/min for $10 \mathrm{~min}$. The insoluble fat was separated by centrifugation at $4000 \times g$ for $20 \mathrm{~min}$ at room temperature (Centrifuge 5804, Eppendorf AG, Hamburg, Germany). The collected supernatant was used for the future experiments in this study. The extraction process was sequentially repeated three times by adding another $10 \mathrm{~mL}$ of AWME to the remaining fat pellet. Then, supernatants were combined together and concentrated under the vacuum (Concentrator plus, Eppendorf AG, Hamburg, Germany) at $45^{\circ} \mathrm{C}$ during $13 \mathrm{~h}$ to obtain the $130.3 \mathrm{mg} / \mathrm{mL}$ of extracted dry substance from the larvae fat. The concentrated extract was stored at $4{ }^{\circ} \mathrm{C}$ until needed.

\subsection{Agar Disk Diffusion Assay}

The diameters of growth inhibition zone for all tested bacteria was measured according to [19]. The bacteria was incubated overnight in $10 \mathrm{~mL}$ of LB broth at $28 \pm 0.5^{\circ} \mathrm{C}$, then adjusted to the density of $5 \times 10^{5}(\mathrm{CFU} / \mathrm{mL})$. MHA petri dishes were streaked with bacterial culture by cotton swab. Then, $50 \mu \mathrm{L}$ of extract solution were added on $6 \mathrm{~mm}$ discs under sterile conditions followed by drying at ambient conditions for $30 \mathrm{~min}$. As a negative control, $50 \mu \mathrm{L}$ of the extraction reagent (AWM) was used, and as a positive control, $50 \mu \mathrm{L}$ of antibiotics penicillin-streptomycin mixture $(5000 \mathrm{U} / \mathrm{mL}$ and $5000 \mu \mathrm{g} / \mathrm{mL} /$ disk) was used. The discs were placed on the surface of the agar plates and incubated at $28 \pm 0.5^{\circ} \mathrm{C}$ for $24 \mathrm{~h}$. The diameters of bacterial inhibition zones surrounded the discs were measured in $24 \mathrm{~h}$. All experiments were performed twice in duplicates.

\subsection{Turbidimetric Assay}

The overnight bacteria culture was adjusted to the density of $5 \times 10^{6}(\mathrm{CFU} / \mathrm{mL})$ in fresh LB broth. AWME was diluted in LB broth to $50 \mathrm{mg} / \mathrm{mL}$ concentration. $100 \mu \mathrm{L}$ of bacteria with $5 \times 10^{6}(\mathrm{CFU} / \mathrm{mL})$ concentration was loaded in each well of 96-well plate (TPP, Trasadingen, Switzerland). Then, the larvae 
fat extract was subjected to two-fold dilutions in the same plate by adding $100 \mu \mathrm{L}$ of start extract concentration of $50 \mathrm{mg} / \mathrm{mL}$ in the first well following by serial of dilutions to get the row of relevant AWME concentrations as $25,12.5,6.25,3.13,0.78,0.195,0.097$, and $0.00 \mathrm{mg} / \mathrm{mL}$ in the wells. The negative (100 $\mu \mathrm{L}$ of AWM extraction reagent) and positive (100 $\mu \mathrm{L}$ of penicillin-streptomycin (P/S) with $50 \mu \mathrm{g} / \mathrm{mL}$ concentration) controls were subjected to the two-fold dilutions as described above for AWME dilutions. Each dilution was used in triplicates. Then, the plates were sealed with a film, and incubated at $28 \pm 0.5^{\circ} \mathrm{C}$ with shaking at $130 \mathrm{rpm} / \mathrm{min}$ for $24 \mathrm{~h}$. The optical density was measured at intervals of every $2 \mathrm{~h}$ from $0 \mathrm{~h}$ to $24 \mathrm{~h}$ at $600 \mathrm{~nm}$ by using CLARIOstar microplate reader (BMG LABTECH, Ortenberg, Germany).

\subsection{Determination of Minimum Inhibitory Concentrations by Turbidimetric Assay}

The minimum inhibitory concentrations (MICs) was determined according to [20]. The $100 \mu \mathrm{L}$ of larvae extract with $100 \mathrm{mg} / \mathrm{mL}$ of started concentration was diluted in 96-well plates to the final concentrations of $25,12.5,6.25,3.13,0.78,0.195$, and $0.097 \mathrm{mg} / \mathrm{mL}$ through a serial of dilutions by $100 \mu \mathrm{L}$ of tested bacteria mixture started with $5 \times 10^{6}(\mathrm{CFU} / \mathrm{mL})$ density. Similar to the fat extract, we prepared the positive control $(\mathrm{P} / \mathrm{S})$ in the same range of concentrations. The plates were incubated at $28 \pm 0.5^{\circ} \mathrm{C}$ with shaking $130 \mathrm{rpm} / \mathrm{min}$ for $24 \mathrm{~h}$. The MICs were defined by the visual inspection as the lowest concentration of AWME that were able to inhibit the bacterial growth. The experiment was performed under sterile conditions to avoid any unwanted bacterial contaminations.

\subsection{Determination of Half of Inhibitory Concentration $\left(I C_{50}\right)$}

The half of inhibitory concentration $\left(\mathrm{IC}_{50}\right)$ was calculated from the Turbidimetric assay at $6 \mathrm{~h}, 12 \mathrm{~h}$, and $24 \mathrm{~h}$. Briefly, the $100 \mu \mathrm{L}$ of bacterial suspension at the final density $5 \times 10^{5}(\mathrm{CFU} / \mathrm{mL})$ was added to 96-well plates, which contained an aliquot of $100 \mu \mathrm{L}$ of BSFL fat extract previously diluted in LB broth to the final concentrations of $25,12.5,3.13,1.56,0.78,0.39,0.195,0.097$, and $0.00 \mathrm{mg} / \mathrm{mL}$. Positive control $(\mathrm{P} / \mathrm{S})$ was prepared and added as mentioned above. For each sample, $\mathrm{IC}_{50}$ was determined using non-linear regression mode of GraphPad PRISM ${ }^{\mathrm{TM}}$ software, version of 6.07 (Graph Pad Software, Inc., San Diego, CA, USA). The $\mathrm{IC}_{50}$ values are expressed as the inhibitory dose of AWME that reduced the tested bacteria growth by $50 \%$ of the untreated bacteria control.

\subsection{Determination of Minimum Bactericidal Concentration (MBC)}

Minimum bactericidal concentration (MBC) for AWME and positive control (P/S) was determined according to [21,22] with a slight modification. Thus, $50 \mu \mathrm{L}$ of the mixture from the $1 \times \mathrm{MIC}(0.78 \mathrm{mg} / \mathrm{mL})$, $2 \times$ MIC $(1.56 \mathrm{mg} / \mathrm{mL})$ and $3 \times$ MIC $(3.125 \mathrm{mg} / \mathrm{mL})$ wells of the TB assay was sub-cultured on MH agar plates after $24 \mathrm{~h}$ of the incubation. MH agar plates were further incubated for $48 \mathrm{~h}$. The lowest concentration of the AWME extracts, at which no bacterial growth was observed, was accepted as MBC for this strain. The experiment was repeated in triplicate for each strain.

\subsection{Gas Chromatography-Mass Spectrometry (GC-MS) Analysis}

The GC-MS analysis of the BSFL AWME was conducted by using GCMS-QP2010 ultra mass spectrometer (Shimadzu, Canby, OR, USA) and PAL 5000 autosampler (Gerstel, Zwingen, Switzerland). Separation of bioactive compounds was carried out by using capillary column DB-5ms (30 $\mathrm{m} \times 0.25 \mathrm{~mm}$ $\times 0.25 \mathrm{~mm}$ ) coated with non-polar silphenylene polymer virtually equivalent polarity to $5 \%$ diphenyl and $95 \%$ dimethylpolysiloxane stationary phase (Restek, Bellefonte, PA, USA. Operation conditions were as follows: the injector and detector temperatures were set at $280{ }^{\circ} \mathrm{C}$ and $250{ }^{\circ} \mathrm{C}$, respectively. The $1 \mu \mathrm{L}$ of BSFL AWME solution was injected automatically by split-less mode. The temperature program was as follow: the initial temperature $40^{\circ} \mathrm{C}$ was held for $1 \mathrm{~min}$, and then it was increased at $15^{\circ} \mathrm{C} / \mathrm{min}$ until $210^{\circ} \mathrm{C}$, held for $0 \mathrm{~min}$, increased at $5^{\circ} \mathrm{C} / \mathrm{min}$ until $216^{\circ} \mathrm{C}$, held for $0 \mathrm{~min}$, increased at $40^{\circ} \mathrm{C} / \mathrm{min}$ until $300^{\circ} \mathrm{C}$, and finally held for $14.87 \mathrm{~min}$. The helium was used as the carrier gas, with a linear velocity of column flow from 1 to $15 \mathrm{~mL} / \mathrm{min}$, and the column head pressure was $50.4 \mathrm{kPa}$. 
Fatty acids content of AWME were identified by using a mass spectrometer (MS). MS operated in the electron ionization mode and mass spectra were collected within $\mathrm{m} / \mathrm{z}$ from 33 to 1000 . The qualitative analysis of compounds based on the comparison of their spectral mass with those of NIST mass spectra database (NIST 08, MS v.2., MD 20899, 2008). Compound chromatogram peaks' matching similarity index (SI) greater than $70 \%$ in NIST library were assigned.

\subsection{Statistical Analysis}

Statistical analyses were performed using the two-way ANOVA and post-hoc Tukey's tests $(p<0.05)$. All results assessed by the standard deviation (SD) and standard error of the mean (SEM) using built-in algorithms of GraphPad Prism ${ }^{\mathrm{TM}}$ software, version 6.07 (San Diego, CA, USA).

\section{Results}

\subsection{Extraction of Bioactive Compounds from the Hermetia illucens Larvae Fat}

To choose the best solvent for the extraction of the soluble form of antimicrobial constituents, we tested the BFSL fat solubility in 21 organic solvents individually or in combination. To increase the yield of the solvent extracted chemicals, we managed the concentration of fat in the range $10 \%$ to $30 \%$ $(w / v)$ for each solvent at room temperature. The fat heating under hot tap water and testing of chemicals in the mixture with $\mathrm{H}_{2} \mathrm{O}$ used to increase its hydrophilicity. We found that the fat was soluble in almost all non-polar reagents without a difference in its hydrophobicity (Table 1). However, we observed the formation of the light fraction on the top of double layers, when extracted by hydrophobic solvents such as $\mathrm{CHCl}_{3}, \mathrm{DMSO}$, and $\mathrm{C}_{6} \mathrm{H}_{14}$. We found that during the dissolution of BFSL fat in hydrophilic reagents, $\mathrm{CH}_{3} \mathrm{CN}, \mathrm{CH}_{3} \mathrm{OH}$, or $\mathrm{C}_{15} \mathrm{H}_{11} \mathrm{OH}$, the cloudy layer formed at the bottom of the extracted solvent. The increasing fat concentration from $10 \%$ to $30 \%(w / v)$ revealed the decreasing solubility of fat almost for every organic solvent, except for tetrachloromethane, pentanol, and a mixture of chloroformdimethylformamide $(9: 1, v / v)$ as shown in Supplementary 3.

Table 1. Assessment of BSFL fat solubility. BSFL fat solubilized in various single organic solvents or a combination of two. To increase hydrophilicity, the organic reagents diluted in 10-fold with $\mathrm{H} 2 \mathrm{O}$. The solubility of BSFL fat tested in the range $10 \%$ to $30 \%$ concentration. Solubility marks: (+) soluble; ( \pm ) partially soluble; (- - -) insoluble.

\begin{tabular}{|c|c|c|c|c|c|c|c|c|c|c|}
\hline \multirow{2}{*}{$\begin{array}{c}\begin{array}{c}\text { BSFL Dilution } \\
\text { Solvent }\end{array} \\
\mathrm{CCl}_{4}\end{array}$} & \multicolumn{2}{|c|}{$\begin{array}{c}10 \% \text { Fat } \\
+\mathrm{H}_{2} \mathrm{O}\end{array}$} & \multicolumn{2}{|c|}{$\begin{array}{c}15 \% \text { Fat } \\
+\mathrm{H}_{2} \mathrm{O}\end{array}$} & \multicolumn{2}{|c|}{$\begin{array}{c}20 \% \text { Fat } \\
+\mathrm{H}_{2} \mathrm{O}\end{array}$} & \multicolumn{2}{|c|}{$\begin{array}{c}25 \% \text { Fat } \\
+\mathrm{H}_{2} \mathrm{O}\end{array}$} & \multicolumn{2}{|c|}{$\begin{array}{c}30 \% \text { Fat } \\
+\mathrm{H}_{2} \mathrm{O}\end{array}$} \\
\hline & + & \pm & + & \pm & + & \pm & + & -- & + &.-- \\
\hline $\mathrm{C}_{6} \mathrm{H}_{14}$ & + & + & + & + & + & \pm & + &.- & \pm &.- \\
\hline $\mathrm{CH}_{2} \mathrm{Cl}_{2}$ & + & \pm & + & + & + & + & \pm &.- & \pm &.- \\
\hline DMSO & \pm & + & \pm & + & \pm & + & \pm & $-\ldots$ & $-\ldots$ & - \\
\hline $\mathrm{CHCl}_{3}$ & + & $-\ldots$ & \pm & \pm & \pm & \pm & \pm & $-\ldots$ & \pm & - \\
\hline DMFA & + & \pm & \pm & \pm & \pm & \pm & \pm & - & \pm & - \\
\hline $\mathrm{CH}_{3} \mathrm{CN}$ & + & \pm & \pm & \pm & \pm & \pm & \pm & $\ldots$ & \pm & - \\
\hline $\mathrm{CH}_{3} \mathrm{OH}$ & \pm & \pm & - & - & - & - & - & - & - &.- \\
\hline $\mathrm{C}_{5} \mathrm{H}_{11} \mathrm{OH}$ & + & \pm & + & \pm & + & \pm & + &.- & + &.- \\
\hline $\mathrm{C}_{2} \mathrm{H}_{5} \mathrm{OH}$ & \pm & + & \pm & \pm & \pm & \pm & \pm &.- & \pm &.- \\
\hline $\mathrm{C}_{3} \mathrm{H}_{6} \mathrm{O}$ & \pm & + & \pm & + & \pm & + & \pm & -- & \pm & -- \\
\hline $\begin{array}{c}\mathrm{CHCl}_{3}+\mathrm{DMFA} \\
(9: 1, v / v)\end{array}$ & + & \pm & + & \pm & + & \pm & + & - - & + & - - - \\
\hline $\begin{array}{c}\mathrm{C}_{6} \mathrm{H}_{14}+\mathrm{C}_{3} \mathrm{H}_{6} \mathrm{O} \\
(9: 1, v / v)\end{array}$ & + & \pm & + & \pm & + & \pm & \pm & - - - & \pm & - - \\
\hline $\begin{array}{c}\mathrm{C}_{6} \mathrm{H}_{14}+\mathrm{CH}_{3} \mathrm{CN} \\
(9: 1, v / v)\end{array}$ & + & \pm & + & \pm & + & \pm & \pm & - - & \pm & - - - \\
\hline
\end{tabular}


Table 1. Cont.

\begin{tabular}{|c|c|c|c|c|c|c|c|c|c|c|}
\hline \multirow{2}{*}{$\begin{array}{c}\begin{array}{c}\text { BSFL Dilution } \\
\text { Solvent }\end{array} \\
\begin{array}{c}\mathrm{DMSO}+\mathrm{C}_{3} \mathrm{H}_{6} \mathrm{O} \\
(9: 1, v / v)\end{array}\end{array}$} & \multicolumn{2}{|c|}{$\begin{array}{c}10 \% \text { Fat } \\
+\mathrm{H}_{2} \mathrm{O}\end{array}$} & \multicolumn{2}{|c|}{$\begin{array}{c}15 \% \text { Fat } \\
+\mathrm{H}_{2} \mathrm{O}\end{array}$} & \multicolumn{2}{|c|}{$\begin{array}{c}20 \% \text { Fat } \\
+\mathrm{H}_{2} \mathrm{O}\end{array}$} & \multicolumn{2}{|c|}{$\begin{array}{c}25 \% \text { Fat } \\
+\mathrm{H}_{2} \mathrm{O}\end{array}$} & \multicolumn{2}{|c|}{$\begin{array}{c}30 \% \text { Fat } \\
+\mathrm{H}_{2} \mathrm{O}\end{array}$} \\
\hline & + & + & \pm & + & \pm & \pm & \pm & -- & \pm & -- \\
\hline $\begin{array}{c}\mathrm{DMSO}+\mathrm{CH}_{3} \mathrm{CN} \\
(9: 1, v / v)\end{array}$ & + & + & \pm & + & \pm & + & \pm & - - - & \pm & -- \\
\hline $\begin{array}{c}\mathrm{CHCl} 3+\mathrm{CH} 3 \mathrm{CN} \\
(9: 1, v / v)\end{array}$ & + & \pm & + & \pm & + & \pm & \pm & - - - & \pm & -- \\
\hline $\begin{array}{c}\mathrm{CHCl}_{3}+\mathrm{C}_{3} \mathrm{H}_{6} \mathrm{O} \\
(9: 1, v / v)\end{array}$ & + & + & \pm & \pm & \pm & \pm & \pm & - - - & \pm & -- \\
\hline $\begin{array}{c}\mathrm{C}_{5} \mathrm{H}_{11} \mathrm{OH}+ \\
\mathrm{C}_{3} \mathrm{H}_{6} \mathrm{O} \\
(9: 1, v / v)\end{array}$ & + & \pm & + & \pm & \pm & \pm & \pm & - - - & \pm & -- \\
\hline $\begin{array}{c}\mathrm{C}_{5} \mathrm{H}_{11} \mathrm{OH}+ \\
\text { DMSO } \\
(9: 1, v / v)\end{array}$ & \pm & \pm & \pm & \pm & \pm & \pm & -- & - - & -- & - \\
\hline
\end{tabular}

When we evaluated the fractions of soluble or partially soluble fat on its antimicrobial efficacy against phytopathogenic bacteria, none of them demonstrated a positive result (data not shown). Considering the empirically observed positive influence of hydrophilicity on BSFL fat solubility, we increased the content of water and methanol in extracting reagent. As the larvae fat contained free fatty acids, the presence of organic acids might catalyze the cascade of lipid hydrolysis at increased temperature by the scheme:

$$
\begin{aligned}
\mathrm{RCOOR}^{\prime}+\mathrm{H}_{2} \mathrm{O} & \rightleftharpoons \mathrm{RCOOH}+\mathrm{R}^{\prime} \mathrm{OH} & \text { (Hydrolysis) } \\
\mathrm{RCOOH}+\mathrm{R}^{\prime} \mathrm{OH} & \rightleftharpoons \mathrm{RCOOR}^{\prime}+\mathrm{H}_{2} \mathrm{O} & \text { (Esterification) } \\
\mathrm{RCOO} \mathrm{R}^{\prime}+\mathrm{R}^{\prime \prime} \mathrm{OH} & \rightleftharpoons \mathrm{RCOO} \mathrm{R}^{\prime \prime}+\mathrm{R}^{\prime} \mathrm{OH} & \text { (Alcoholises) }
\end{aligned}
$$

The reactions shown in Equations (1)-(3) are the most widely used in fatty acid and lipid chemistry of conversion the acids to esters or vice versa. We optimized the BSFL fat extraction conditions and formulated its composition as a mixture of deionized water:methanol:hydrochloric acid at volume ratio 90:9:1 (\%) (AWM). In our mix, the $\mathrm{HCl}$ plays an essential catalytic role providing a higher level of extraction of fatty acids from BSFL fat. In addition to fatty acids, these reactions produce the methyl esters synthesis, which is the starting point for the most oleochemical and glycerol production as valuable byproducts. The well-known alcoholysis or methanolysis of triacylglycerols used to prepare methyl esters; a process frequently referred to as transesterification [23]. Using AWM solvent, we were able to extract up to $4.33 \%$ of the active fatty acids and its derivatives from BSFL fat.

\subsection{Examination of Antibacterial Activity against Phytopathogens}

The antibacterial effect of acidic water-methanol extract (AWME) from BSFL fat against five significant phytopathogens was measured using the agar disk diffusion assay. The results of bacterial growth inhibition of Xanthomonas campestris pv. campestris and Pectobacterium astrosepticum during $12 \mathrm{~h}$ and $24 \mathrm{~h}$ of treatment with different concentrations of AWME in the range 6.5 to $50 \mathrm{mg} / \mathrm{mL}$ shown in Figure 1. 
Time

Xanthomonas campestris pv. campestris

$12 \mathrm{~h}$

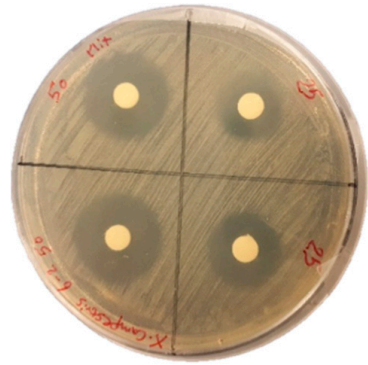

(a)

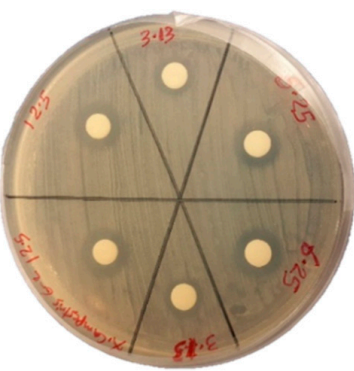

(b)

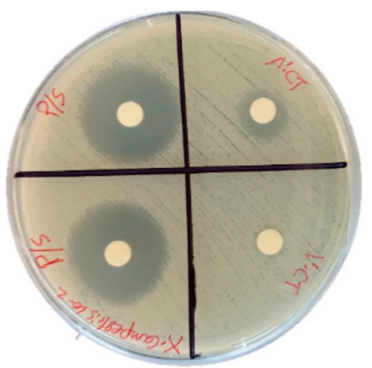

(c)

$24 \mathrm{~h}$

Xanthomonas campestris pv. campestris

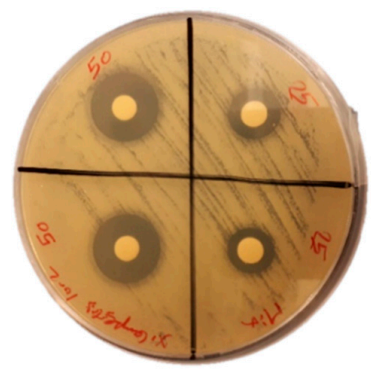

(a)

$12 \mathrm{~h}$

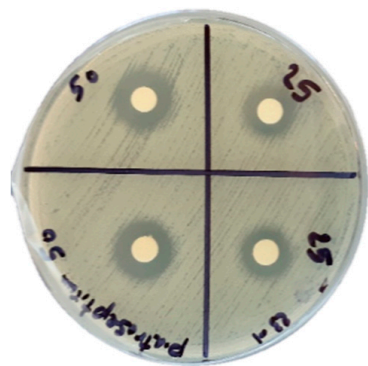

(a)

$24 \mathrm{~h}$

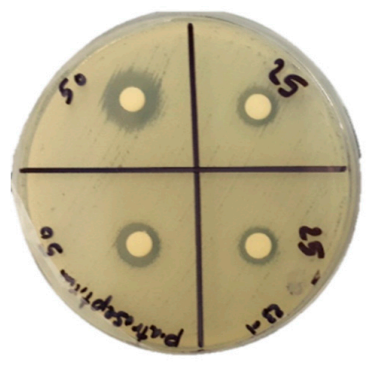

(a)

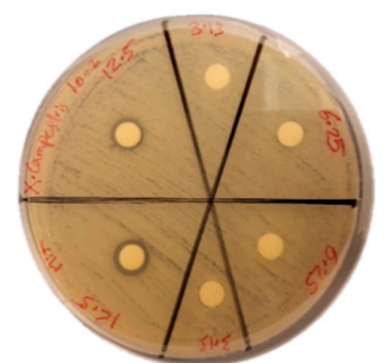

(b)

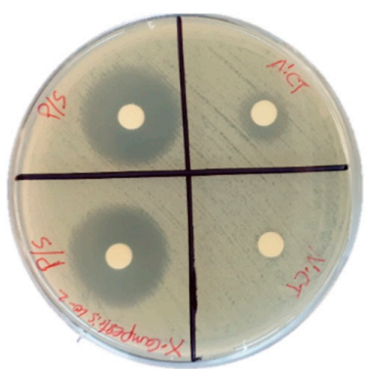

(c)

Pectobacterium atrosepticum

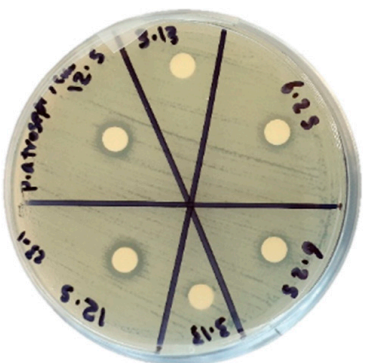

(b)

Pectobacterium atrosepticum

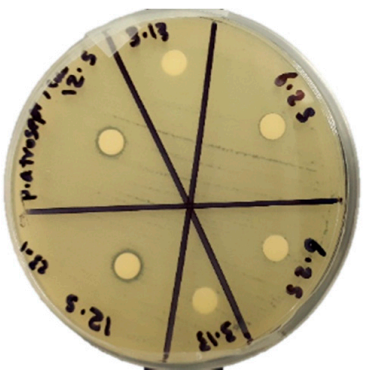

(b)

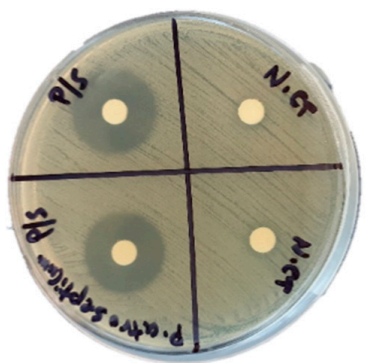

(c)

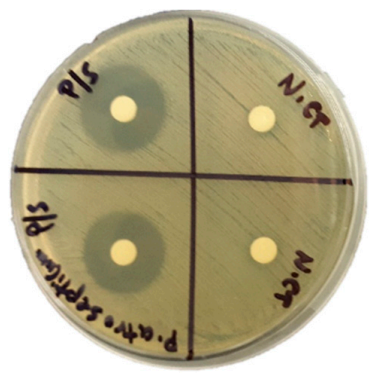

(c)

Figure 1. The bacterial growth inhibition assay. The representative images of zones of bacterial growth inhibition were measured after $12 \mathrm{~h}$ and $24 \mathrm{~h}$ of overnight incubation of the discs loaded on petri dishes agar with Xanthomonas campestris po campestris and Pectobacterium atrosepticum bacteria lawn. The discs with tested samples were loaded with $50 \mu \mathrm{L}$ of AWME from larvae fat with concentrations of 50 and $25 \mathrm{mg} / \mathrm{mL}$ (a); 12.5, 6.25, and $3.13 \mathrm{mg} / \mathrm{mL}(\mathbf{b}) ; 50 \mu \mathrm{L}$ of $\mathrm{P} / \mathrm{S}$ samples with concentration $5000 \mathrm{U} / \mathrm{mL}-5000 \mu \mathrm{g} / \mathrm{mL}$ was used as positive control (c). The $50 \mu \mathrm{L}$ of pure AWM extracting solution used as a negative control (N-CT) (c). All samples were loaded in duplicates. 
AWME effectively inhibited bacterial growth for all tested Xcc, Pagg, Dsol, Pcc, and Pba pathogenic bacteria (Table 2). The AWME suppressed the growth of all phytopathogens in a dose-dependent manner in the range 50 to $3.13 \mathrm{mg} / \mathrm{mL}$ of tested concentrations (Table 2). Thus, the Pagg and Dsol strains were the most susceptible during $12 \mathrm{~h}$ of incubation to AWME treatment at minimal $3.13 \mathrm{mg} / \mathrm{mL}$ of its concentration. In contrast, for all other strains, the same effect was observed at $12.5 \mathrm{mg} / \mathrm{mL}$ of AWME concentration. The bacteria susceptibility to the AWME treatment decreased after $24 \mathrm{~h}$ of bacteria growth, compared with $12 \mathrm{~h}$, as seen from Figure 1 and Supplementary 1 . The IZD size after $12 \mathrm{~h}$ of incubation was the highest for Xcc strain $(23.5 \pm 035 \mathrm{~mm})$ and lowest for the Pba strain $(14.75 \pm 0.75 \mathrm{~mm})$ at $50 \mathrm{mg} / \mathrm{mL}$ of AWME concentration, while after $24 \mathrm{~h}$ it decreased to $19.0 \pm 0.28 \mathrm{~mm}$ and $12.2 \pm 0.56 \mathrm{~mm}$, respectively. A decrease of AWME level in the range from $50 \mathrm{mg} / \mathrm{mL}$ to $3.13 \mathrm{mg} / \mathrm{mL}$ led to essential IZD size reduction during $12 \mathrm{~h}$ of incubation, compared with $24 \mathrm{~h}$. Thus, for the most susceptible Xcc strain IZD size was decreased by $69.1 \%$ from $23.5 \pm 035 \mathrm{~mm}$ to $7.25 \pm 0.28 \mathrm{~mm}$ after $12 \mathrm{~h}$ of incubation, while after $24 \mathrm{~h}$ only by $57.0 \%$ from $19.0 \pm 0.28 \mathrm{~mm}$ to $8.0 \pm 0.7 \mathrm{~mm}$. The slight fluctuation of IZD size between $20.63 \pm 053-24.0 \pm 0.35 \mathrm{~mm}$ for positive control penicillin/streptomycin at $5000 \mathrm{IU} / \mathrm{mL}$ to $5000 \mu \mathrm{g} / \mathrm{mL}$ loads did not substantially change between $12 \mathrm{~h}$ and $24 \mathrm{~h}$ of incubation. The actual IZD size due to AWME treatment demonstrated a significant difference in comparison to Positive control at ${ }^{* * * *} \mathrm{P}<0.0001$ as shown in Supplementary 1 . These results indicated that chemical compounds extracted from $H$. illucens larvae fat by hydrochloric acid:water:methanol extraction possess efficient antibacterial activity against five plant pathogens.

Table 2. Agar disk diffusion assay. Antibacterial activity was measured using the agar disk diffusion assay against Xanthomonas campestris pv. campestris (Xcc), Pantoea agglomerans (Pagg), Dickeya solani (Dsol), Pectobacterium carotovorum subsp. carotovorum (Pcc), and Pectobacterium atrosepticum (Pba) bacteria strains. The bacteria were exposed to $50,25,12.5,6.25$, and $3.13 \mathrm{mg} / \mathrm{mL}$ of extract from BSFL fat. The zone of bacterial growth inhibition was measured after $12 \mathrm{~h}$ and $24 \mathrm{~h}$ of incubation at $28 \pm 0.5^{\circ} \mathrm{C}$ by the diameter of clear zone surrounding of the discs (in $\mathrm{mm}$ ). Penicillin-streptomycin ( $\mathrm{p} / \mathrm{s}$ ) was used as an antibacterial positive control. The AWME solution was used as negative control. The results presented as means of inhibitory zone \pm standard deviation of three independent experiments in duplicates. ND, not detectable; AWME, extract from BSFL fat; AWM extraction solution: water:methanol:hydrochloric acid $(90: 9: 1, v / v)$.

\begin{tabular}{|c|c|c|c|c|c|c|c|c|c|c|}
\hline \multirow[b]{2}{*}{ AWME } & \multicolumn{2}{|c|}{ Xcc } & \multicolumn{2}{|c|}{ Pagg } & \multicolumn{2}{|c|}{ Dsol } & \multicolumn{2}{|c|}{ Pcc } & \multicolumn{2}{|c|}{$\mathrm{Pba}$} \\
\hline & $12 \mathrm{~h}$ & $24 \mathrm{~h}$ & $12 \mathrm{~h}$ & $24 \mathrm{~h}$ & $12 \mathrm{~h}$ & $24 \mathrm{~h}$ & $12 \mathrm{~h}$ & $24 \mathrm{~h}$ & $12 \mathrm{~h}$ & $24 \mathrm{~h}$ \\
\hline 50 & $23.5 \pm 035$ & $19.0 \pm 0.28$ & $15.4 \pm 0.28$ & $12.5 \pm 0.7$ & $18.5 \pm 0.7$ & $14.0 \pm 0.7$ & $20.25 \pm 1.76$ & $14.75 \pm 0.35$ & $14.75 \pm 0.75$ & $12.2 \pm 0.56$ \\
\hline 25 & $16.5 \pm 0.42$ & $12.5 \pm 0.7$ & $10.5 \pm 0.7$ & $8.5 \pm 0.35$ & $14.2 \pm 0.28$ & $11.0 \pm 0.7$ & $13.25 \pm 0.35$ & $10.12 \pm 0.18$ & $12.25 \pm 0.35$ & $9.5 \pm 0.7$ \\
\hline 6.25 & $7.25 \pm 0.28$ & ND & $8.0 \pm 0.7$ & ND & $9.0 \pm 0.7$ & $7.0 \pm 0.0$ & $7.25 \pm 0.35$ & ND & $7.37 \pm 0.18$ & ND \\
\hline 3.13 & ND & ND & $7.0 \pm 0.0$ & ND & $7.0 \pm 0.0$ & ND & ND & ND & ND & ND \\
\hline $\mathrm{P} / \mathrm{S}$ & $23.75 \pm 0.35$ & $24.0 \pm 0.35$ & $20.75 \pm 0.35$ & $21.0 \pm 0.7$ & $23.75 \pm 0.7$ & $23.75 \pm 0.7$ & $21.12 \pm 0.18$ & $21.0 \pm 0.7$ & $21.0 \pm 0.7$ & $20.63 \pm 053$ \\
\hline
\end{tabular}

\subsection{The Potency of AWME from Larvae Fat on Bacteria Growth and Proliferation in Turbidimetric Assay (TB)}

The antimicrobial effects of AWME against plant pathogenic species Xcc, Pagg, Dsol, Pcc and Pba were further evaluated using turbidimetric (TB) assay in the range from 25 to $0.097 \mathrm{mg} / \mathrm{mL}$ of AWME concentration (Figure 2). TB assay results demonstrated the increase of the AWME antimicrobial efficacy in a concentration-dependent manner, similar to the one observed from the agar disk diffusion assay (Figure 1). The measuring of the optical density of the cell suspension at $600 \mathrm{~nm}$ within $24 \mathrm{~h}$ assessed the effect of AWME concentration on bacterial proliferation. As shown in Figure 2, in the presence of $0.39 \mathrm{mg} / \mathrm{mL}$ AWME, the bacterial proliferation was retarded for all strains throughout the experiment except Xcc strain, whose proliferation recovered after $20 \mathrm{~h}$ of incubation. We observed the difference in the rate of proliferation among tested and control groups in the late log phase. This trend continued at the stationary phase, when the cultures reached higher $2.4 \mathrm{OD}_{600}$ for the control group, while the density among AMWE-treated bacteria was in the range of 1.07 to $1.5 \mathrm{OD}_{600}$. Besides, 
the presence of AWME at $0.39 \mathrm{mg} / \mathrm{mL}$ concentration delayed the lag phase time up to $6 \mathrm{~h}$ for Pagg, Pba, and Pcc strains, except Xcc (Figure 2).

Bacteria proliferation in the Penicillin-Streptomycin presence

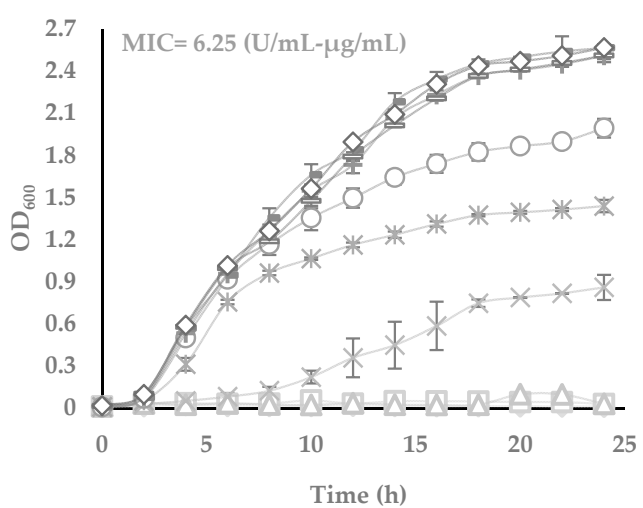

(a)

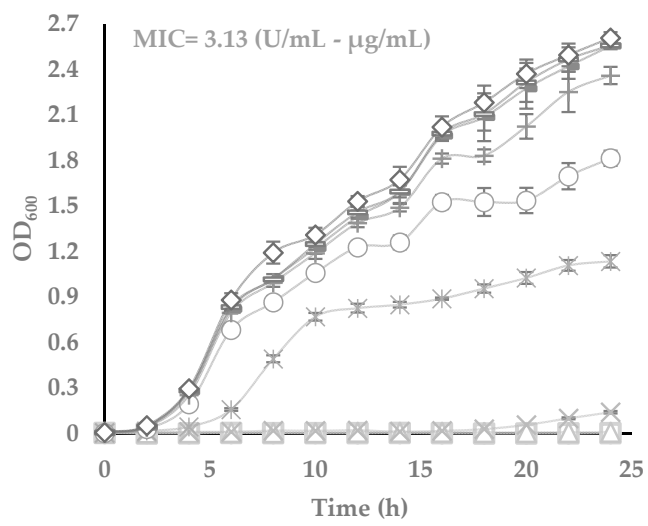

Bacteria proliferation in the AWME presence
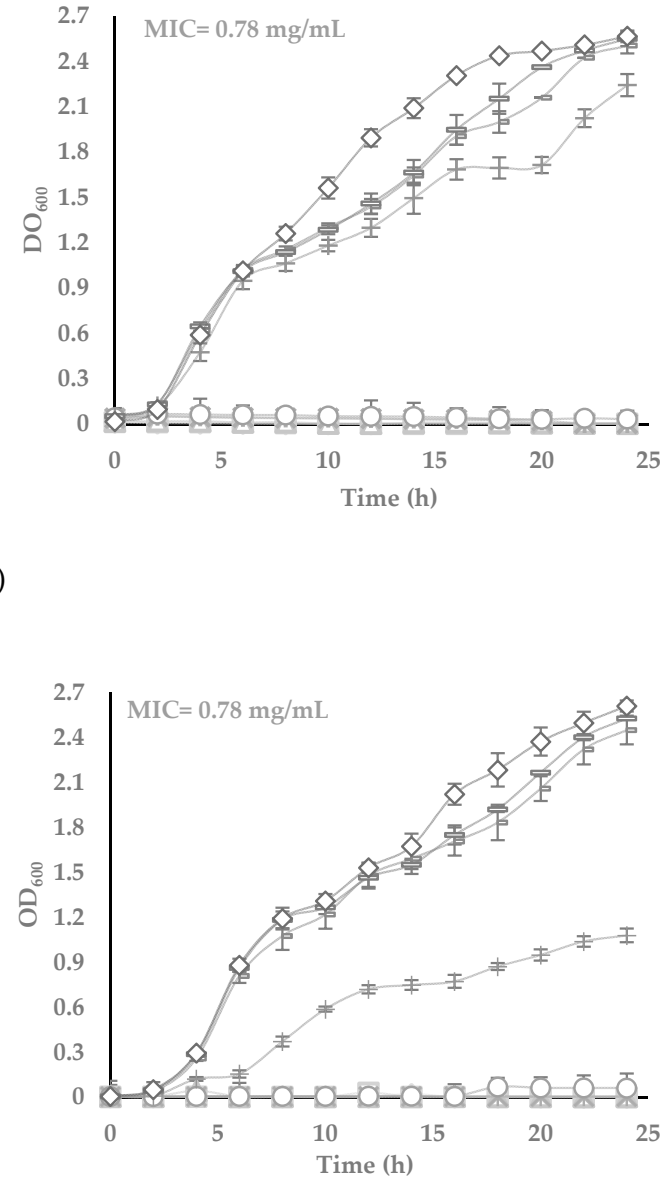

(b)

Figure 2. Cont. 

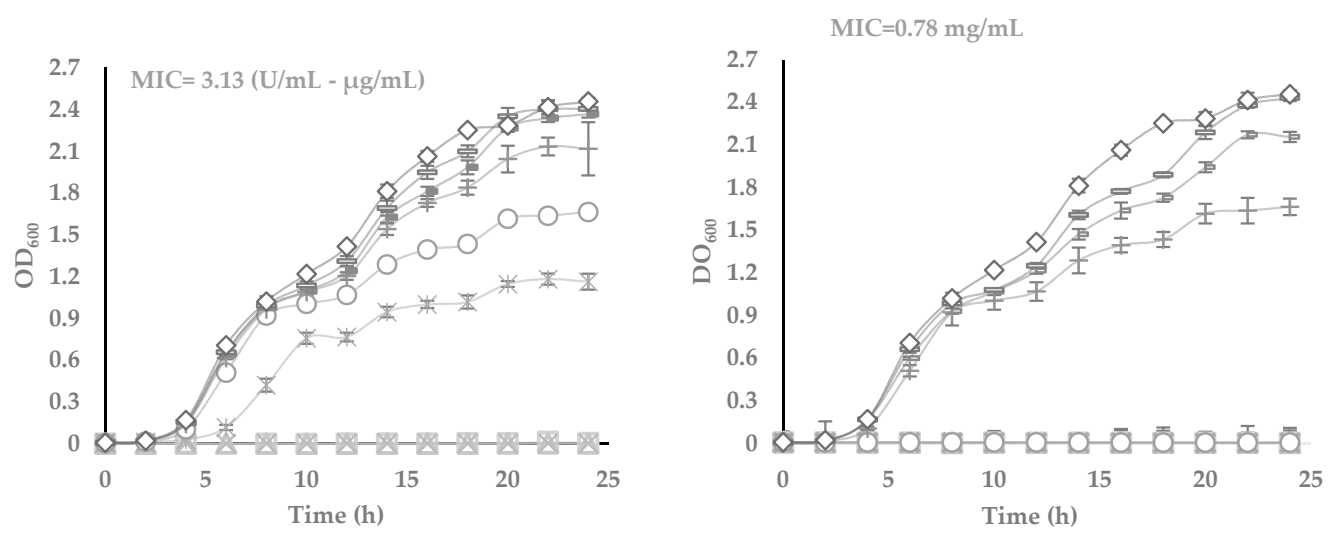

(c)
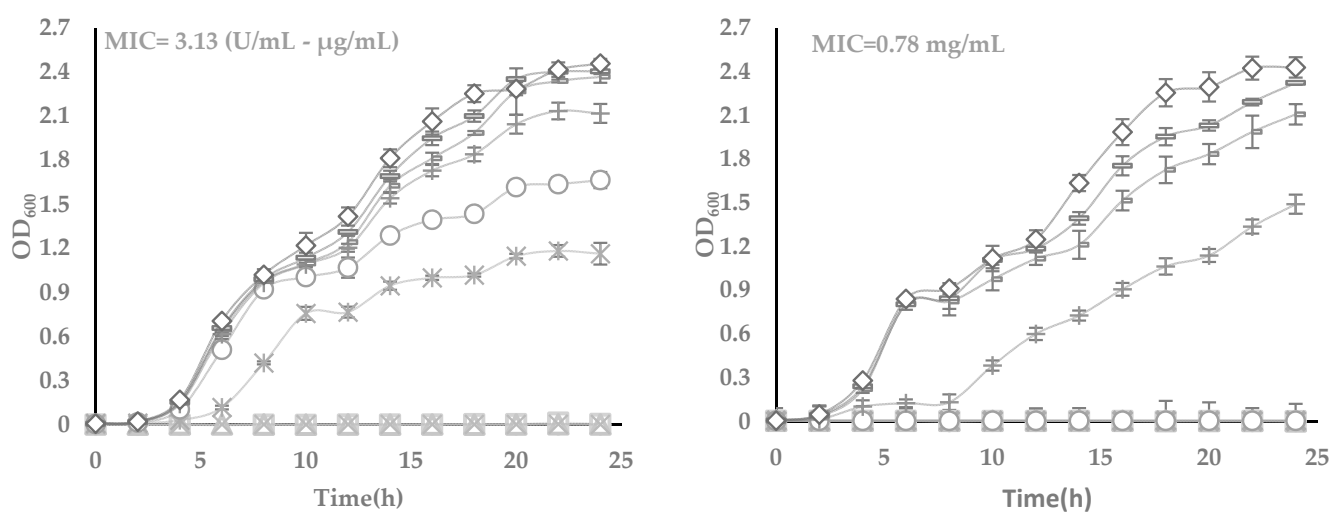

(d)
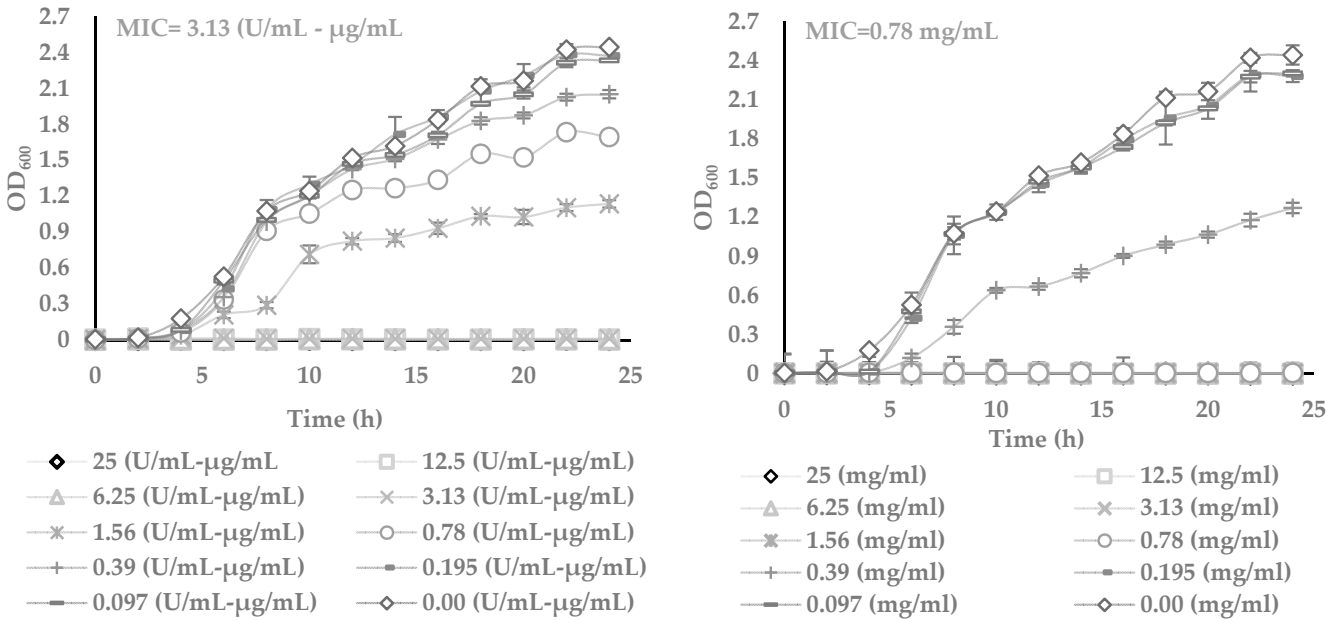

(e)

Figure 2. The turbidimetric assay performed in the sterile 96 -well plates, in the range of 25 to $0.0097 \mu \mathrm{g} / \mathrm{mL}$ of AWME and P/S concentrations, in triplicates. Five bacteria strains tested: (a) Xanthomonas campestris subsp. campestris; (b) Pantoea agglomerans; (c) Dickeya solani; (d) Pectobacterium carotovorum subsp. carotovorum, and (e) Pectobacterium atrosepticum. Minimum inhibitory concentration (MIC) value against bacterial growth was determined for the wells, which appear to stop the growth and remain transparent. Each value represents the mean of three independent experiments $\pm \operatorname{SD}(n=3)$. Differences were considered significant at $p<0.05$. 
The minimum inhibitory concentration (MIC) value was $0.78 \mathrm{mg} / \mathrm{mL}$ for all tested phytopathogens. In comparison, MIC for the positive control penicillin-streptomycin was $3.13 \mathrm{U} / \mathrm{mL}-\mu \mathrm{g} / \mathrm{mL}$ for all strains, except Xcc, which was $6.25 \mathrm{U} / \mathrm{mL}-\mu \mathrm{g} / \mathrm{mL}$. At the same time, TB results showed apparent differences in the susceptibility of tested phytopathogens to the AWME treatment. The minimum bactericidal concentration (MBC), which kills $99.9 \%$ of the bacteria, indicates the antimicrobial potency of AWME. MBC of AWME was $0.78 \mathrm{mg} / \mathrm{mL}$ for all phytopathogenic strains except Pagg, which was the less susceptible to AMWE with MBC $1.56 \mathrm{mg} / \mathrm{mL}$. MBC of the positive control (P/S) was $6.25 \mathrm{U} / \mathrm{mL}-\mu \mathrm{g} / \mathrm{mL}$ only for Xcc strain and 3.125 U/mL- $\mu \mathrm{g} / \mathrm{mL}$ for all other strains (Figure 2). Besides, the BSFL extraction reagent (AWM reagent) further verified as vehicle control for its antibacterial capability within the same range of concentrations as used in the TB assay for AMWE. We found that AWM reagent does not affect all tested bacteria proliferation (data not shown). These results indicate the AWME potency for bacterial growth inhibition, especially of such significant pathogens as Pantoea agglomerans, Dickeya solani and Pectobacterium atrosepticum.

\subsection{Determination of the $50 \%$ Inhibitory Concentration $\left(I_{50}\right.$ ) of the Plant Pathogenic Bacteria}

The effectiveness, as $50 \%$ inhibitory concentration $\left(\mathrm{IC}_{50}\right)$ values of $\mathrm{AWME}$ against the growth of pathogenic species Xcc, Pagg, Dsol, Pcc, and Pba were determined at the $6 \mathrm{~h}$ (early), $12 \mathrm{~h}$ (middle) and $24 \mathrm{~h}$ (late) post-infections based on the dose-response curve data from our previous turbidimetric assay (Table 3).

Table 3. $\mathrm{IC}_{50}$ analysis for phytopathogens treated with AWME from fat vs. positive control (penicillin/streptomycin) for $6 \mathrm{~h}, 12 \mathrm{~h}$, and $24 \mathrm{~h}$.

\begin{tabular}{ccccccc}
\hline & \multicolumn{2}{c}{ IC $_{\mathbf{5 0}}(\boldsymbol{\mu g} / \mathbf{m L})$ of AWME against Treated } \\
Bacteria & \multicolumn{3}{c}{$\begin{array}{c}\text { IC }_{\mathbf{5 0}}(\boldsymbol{\mu g} / \mathbf{m L}) \text { of Positive Control against } \\
\text { Treated Bacteria }\end{array}$} \\
\hline Bacteria species & $6 \mathrm{~h}$ & $12 \mathrm{~h}$ & $24 \mathrm{~h}$ & $6 \mathrm{~h}$ & $12 \mathrm{~h}$ & $24 \mathrm{~h}$ \\
\hline Xcc & $535.1 \pm 0.16$ & $477 \pm 0.25$ & $485.4 \pm 0.4$ & $1.941 \pm 0.15$ & $1.844 \pm 0.26$ & $1.893 \pm 0.36$ \\
Pagg & $299.5 \pm 0.12$ & $383.6 \pm 0.22$ & $366.8 \pm 0.38$ & $1.103 \pm 0.13$ & $1.638 \pm 0.22$ & $1.283 \pm 0.37$ \\
Dsol & $451.8 \pm 0.07$ & $455.1 \pm 0.2$ & $441.8 \pm 0.36$ & $1.060 \pm 0.1$ & $1.675 \pm 0.19$ & $1.306 \pm 0.35$ \\
Pcc & $317.6 \pm 0.07$ & $386.6 \pm 0.22$ & $431 \pm 0.35$ & $1.099 \pm 0.13$ & $1.782 \pm 0.19$ & $1.412 \pm 0.35$ \\
Pba & $290.3 \pm 0.07$ & $376.1 \pm 0.22$ & $400.2 \pm 0.35$ & $1.088 \pm 0.07$ & $1.630 \pm 0.22$ & $1.326 \pm 0.35$ \\
\hline
\end{tabular}

The $\mathrm{IC}_{50}$ values indicated the highest resistance of Xanthomonas campestris subsp. campestris strain to AWME and standard positive control $(\mathrm{P} / \mathrm{S})$ treatments as early as $6 \mathrm{~h}$ post-infection $(535.1 \pm 0.16 \mu \mathrm{g} / \mathrm{mL}$ and $0,1941 \pm 0.15 \mu \mathrm{g} / \mathrm{mL}$, respectively). Interestingly, those $\mathrm{IC}_{50}$ values of $\mathrm{AWME}$ and $\mathrm{P} / \mathrm{S}$ for this strain retained the highest until the $24 \mathrm{~h}$ post-infection compared to all tested strains $(485.4 \pm 0.4 \mu \mathrm{g} / \mathrm{mL}$ and $1.893 \pm 0.36 \mathrm{U} / \mathrm{mL}-\mu \mathrm{g} / \mathrm{mL}$, respectively). On the other hand, the AWME showed the highest activity at $6 \mathrm{~h}$ and retained the highest during $24 \mathrm{~h}$ of monitoring against Pba and Pagg strains with $\mathrm{IC}_{50}$ values equal to $290.3 \pm 0.07$ vs. $400.2 \pm 0.35$ and $299.5 \pm 0.12$ vs. $366.8 \pm 0.38 \mu \mathrm{g} / \mathrm{mL}$, respectively, as shown in Supplementary 2. In addition, the AWME showed high stability and the ability to maintain the consistent responsiveness throughout $24 \mathrm{~h}$ of Dickeya solani strain treatment as seen by the similar $\mathrm{IC}_{50}$ values $(451.8 \pm 0.1,455.1 \pm 0.2$ and $441.8 \pm 0.36 \mu \mathrm{g} / \mathrm{mL}$ at $6 \mathrm{~h}, 12 \mathrm{~h}, 24 \mathrm{~h}$, respectively). In contrast, all recorded $\mathrm{IC}_{50}$ values of the standard positive control have fluctuated within all tested strains. These results demonstrate that proposed AWME from BSFL fat can prevent and sustainably inhibit the proliferation and growth of the plant pathogens as early as $6 \mathrm{~h}$ of incubation, thus having the potential to be used as an antibacterial agent.

\subsection{Gas Chromatography-Mass Spectrometry (GC-MS) Analysis of AWME}

The GC-MS analysis identified 34 organic compounds in the AWME of larvae fat (Figure 3). The chemical profile of these compounds was determined based on the National Institute of Standards and Technology (NIST, USA) database. After comparing the mass spectrum of the unknown AWME 
components with the range of the known chemicals from NIST library, the similarity of GC-MS spectrums more than $70 \%$ was considered as the main criteria for that selection.

\section{Intensity (Arbitrary unit)}

TIC

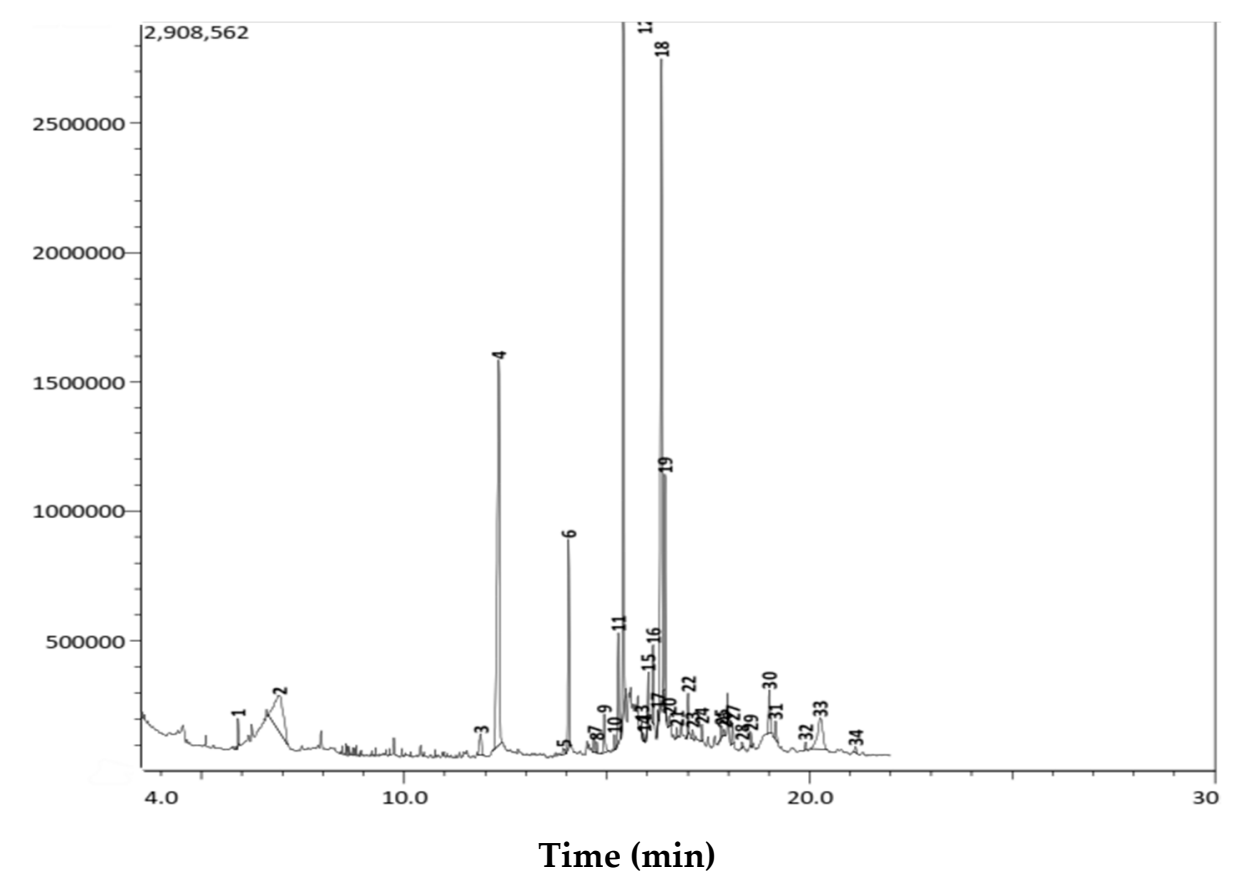

Figure 3. Gas Chromatography-Mass Spectrometry (GC-MS) chromatogram of AWME from BSFL fat. The chemical identity of 34 compounds from AWME fat detected by GC-MS was determined based on NIST Library of chemical compounds.

Among 13 dominant ( $>1 \%$ ) organic compounds, the three most abundant represented more than $50 \%$ of the content, i.e., $22.22 \%$ of octadec-9-eonic acid (18:1, syn. oleic acid), $20.34 \%$ of $n$-hexadecanoic acid (16:0, syn. palmetic acid), and $18.48 \%$ of dodecanoic acid (12:0, syn. lauric acid) (Table 4$)$. The other compounds were presented in trace amount (less than $1 \%$ ), but possessed interesting biological activity and remained as subjects of our further study. Only the highly presented extract $(\geq 1 \%)$ compounds, or the ones characterized in the literature by antimicrobial capacity, were chosen for the final analysis (Table 5). 
Table 4. Chemical content of AWME from BSFL fat.

\begin{tabular}{|c|c|c|c|c|c|c|}
\hline Peak Number & Retention Time & Content $(\%)$ & $\begin{array}{l}\text { Compound Name } \\
\text { (NIST Library) }\end{array}$ & Chemical Formula & Molecular Weight (g/Mol) & Similarity $(\%)$ \\
\hline 1 & 5.9 & 0.61 & 1,2-Propanediol, 3-chloro & $\mathrm{C}_{3} \mathrm{H}_{7} \mathrm{ClO}_{2}$ & 110 & 93 \\
\hline 2 & 6.92 & 6.88 & 1,2,3-Propantriol & $\mathrm{C}_{3} \mathrm{H}_{8} \mathrm{O}_{3}$ & 92 & 97 \\
\hline 3 & 11.888 & 1.02 & beta.-D-Glucopyranose, 1,6-anhydro & $\mathrm{C}_{6} \mathrm{H}_{10} \mathrm{O}_{5}$ & 162 & 92 \\
\hline 4 & 12.335 & 18.48 & Dodecanoic acid (lauric acid) & $\mathrm{C}_{12} \mathrm{H}_{24} \mathrm{O}_{2}$ & 200 & 97 \\
\hline 5 & 13.335 & 0.3 & 2,4-Dodecadienal, (E,E)- (aromatic substance) & $\mathrm{C}_{12} \mathrm{H}_{20} \mathrm{O}$ & 180 & 80 \\
\hline 6 & 14.059 & 5.59 & Tetradecanoic acid (myristic acid) & $\mathrm{C}_{14} \mathrm{H}_{28} \mathrm{O}_{2}$ & 228 & 97 \\
\hline 7 & 14.682 & 0.41 & Dodecanoic acid, ethenyl ester (lauric acid vinyl ester & $\mathrm{C}_{14} \mathrm{H}_{26} \mathrm{O}_{2}$ & 226 & 81 \\
\hline 8 & 14.753 & 0.24 & Pentadecanoic acid (saturated fatty acid) & $\mathrm{C}_{15} \mathrm{H}_{30} \mathrm{O}_{2}$ & 242 & 83 \\
\hline 9 & 14.937 & 1.17 & 3-Cyclopentylpropionic acid, 2-dimethylaminoethyl ester & $\mathrm{C}_{12} \mathrm{H}_{23} \mathrm{NO}_{2}$ & 213 & 91 \\
\hline 10 & 15.186 & 0.35 & Hexadecanoic acid methyl ester (palmetic acid methyl ester) & $\mathrm{C}_{17} \mathrm{H}_{34} \mathrm{O}_{2}$ & 270 & 88 \\
\hline 11 & 15.286 & 3.02 & cis-9-Hexadecenoic acid (palmetoleic acid) & $\mathrm{C}_{16} \mathrm{H}_{30} \mathrm{O}_{2}$ & 254 & 96 \\
\hline 12 & 15.412 & 20.34 & n-Hexadecanoic acid (palmetic acid) & $\mathrm{C}_{16} \mathrm{H}_{32} \mathrm{O}_{2}$ & 256 & 96 \\
\hline 13 & 15.858 & 0.18 & Dodecanoic acid, 2-hydroxy-1-(hydroxymethyl) ethyl ester & $\mathrm{C}_{15} \mathrm{H}_{30} \mathrm{O}_{4}$ & 274 & 73 \\
\hline 14 & 15.918 & 0.14 & Hexadecanoic acid & $\mathrm{C}_{16} \mathrm{H}_{32} \mathrm{O}_{2}$ & 256 & 78 \\
\hline 15 & 16.02 & 1.32 & Dodecanoic acid, 2,3-dihydroxypropyl ester (monolaurin) & $\mathrm{C}_{15} \mathrm{H}_{30} \mathrm{O}_{4}$ & 274 & 83 \\
\hline 16 & 16.138 & 1.62 & 9-Octadecenoic acid (Z)-, methyl ester (oleic acid methyl ester) & $\mathrm{C}_{19} \mathrm{H}_{36} \mathrm{O}_{2}$ & 296 & 87 \\
\hline 17 & 16.257 & 0.34 & Octadecanoic acid, methyl ester (stearic acid methyl ester) & $\mathrm{C}_{19} \mathrm{H}_{38} \mathrm{O}_{2}$ & 298 & 86 \\
\hline 18 & 16.347 & 22.22 & Octadec-9-eonic acid (oleic acid & $\mathrm{C}_{18} \mathrm{H}_{34} \mathrm{O}_{2}$ & 282 & 95 \\
\hline 19 & 16.437 & 5.34 & Octadecanoic acid (stearic acid) & $\mathrm{C}_{18} \mathrm{H}_{36} \mathrm{O}_{2}$ & 284 & 94 \\
\hline 20 & 16.537 & 0.27 & Linoleic acid ethyl ester & $\mathrm{C}_{20} \mathrm{H}_{36} \mathrm{O}_{2}$ & 308 & 75 \\
\hline 21 & 16.721 & 0.23 & 9,12-Octadecadienoic acid (Z,Z)-(linoleic acid) & $\mathrm{C}_{18} \mathrm{H}_{32} \mathrm{O}_{2}$ & 280 & 89 \\
\hline 22 & 17.002 & 0.97 & Fumaric acid, 2-dimethylaminoethyl heptadecyl ester & $\mathrm{C}_{25} \mathrm{H}_{47} \mathrm{NO}_{4}$ & 425 & 82 \\
\hline 23 & 17.114 & 0.24 & Tetradecanoic acid, 2-hydroxy-1-(hydroxymethyl) ethyl ester & $\mathrm{C}_{17} \mathrm{H}_{34} \mathrm{O}_{4}$ & 304 & 86 \\
\hline 24 & 17.346 & 0.36 & Eicosanoic acid (Arachidic acid) & $\mathrm{C}_{20} \mathrm{H}_{40} \mathrm{O}_{2}$ & 312 & 92 \\
\hline 25 & 17.821 & 0.35 & Octanoic acid, 2-dimethylaminoethyl ester & $\mathrm{C}_{12} \mathrm{H}_{25} \mathrm{NO}_{2}$ & 215 & 87 \\
\hline 26 & 17.902 & 0.15 & cis-9-Hexadecenal & $\mathrm{C}_{16} \mathrm{H}_{30} \mathrm{O}$ & 238 & 83 \\
\hline 27 & 18.1 & 0.51 & Hexadecanoic acid, 2-hydroxy-1-(hydroxymethyl) ethyl ester & $\mathrm{C}_{19} \mathrm{H}_{38} \mathrm{O}_{4}$ & 330 & 94 \\
\hline 28 & 18.336 & 0.15 & 9-Octadecanoic acid (Z)- & $\mathrm{C}_{18} \mathrm{H}_{34} \mathrm{O}_{2}$ & 282 & 83 \\
\hline 29 & 18.551 & 0.33 & Tetradecanamide & $\mathrm{C}_{14} \mathrm{H}_{29} \mathrm{NO}$ & 227 & 91 \\
\hline 30 & 19.011 & 1.45 & 9-Octadecenoic acid, 1,2,3-propanetriyl ester, (E,E,E)- & $\mathrm{C}_{57} \mathrm{H}_{104} \mathrm{O}_{6}$ & 884 & 93 \\
\hline 31 & 19.162 & 0.68 & Oleoyl chloride & $\mathrm{C}_{18} \mathrm{H}_{33} \mathrm{ClO}$ & 300 & 90 \\
\hline 32 & 19.905 & 0.22 & Octadecanamide & $\mathrm{C}_{18} \mathrm{H}_{37} \mathrm{NO}$ & 283 & 92 \\
\hline 33 & 20.262 & 3.52 & Dodecanoic acid, 1,2,3-propanetriyl ester & $\mathrm{C}_{39} \mathrm{H}_{4} \mathrm{O}_{6}$ & 638 & 85 \\
\hline 34 & 21.134 & 0.2 & Cholesterol, pentafluoropropionate & $\mathrm{C}_{30} \mathrm{H}_{45} \mathrm{~F}_{5} \mathrm{O}_{2}$ & 532 & 88 \\
\hline
\end{tabular}




\section{Discussion}

The Black Soldier Fly (BSF) H. illucens is a valuable natural resource of biologically active compounds and one of the richest among other insects in the lipids, which can reach up to $45 \%$ depending on the rearing source [24]. The composition of lipids varies depending on the method of larvae processing that can yield various fatty acids (FAs) profile [25]. The larvae's lipid profile is mainly rich in lauric, myristic, palmitic, oleic, capric, linoleic, and other medium-chain fatty acids. Thus, myrestic acid has a broad spectrum of antibacterial effects [26], larvaecidal and repellent activities [27]. Choi and Jiang [28] reported the activity of hexanedioic acid extracted from BSFL against Gram-positive and Gram-negative bacteria. Makkar et al., 2014 [15] reported a high nutritional value of unsaturated oleic (18:1, n-9) and linoleic acids (18:2, n-6) from BSFL. Besides, BSFL reaches in medium-chain lauric acid with known antimicrobial activity through the disruption of the cell membrane [29]. Lauric acid and its phenolic compounds derivatives have a proven record of antimicrobial activity against lipid-coated viruses such as HIV and measles, E. coliform and Clostridium bacteria, and pathogenic protozoans such as Coccidiosis [30,31].

In this study, for the first time, we used the $H$. illucens fat manufactured through the direct pressing of the alive fly larvae as a source for FAs isolation and further characterization of AWME antimicrobial activity. In general, the low $\mathrm{pH}$ facilitates and enriches the FAs extraction, and this approach was successfully used for BSFL lipid extraction from the aqueous layer with different organic acids [32]. We developed a new composition of the extraction solution as a combination of water-methanol-hydrochloric acid in the ratio 90:9:1 (v/v), respectively. Using this solution, we were able to extract $4.43 \%$ of FAs from BSFL fat, compared to $0.52 \%$ extracted by water [33] and $2 \%$ extracted by methanol [28]. The FAs profile identified by GC-MS analysis, and presented in Table 4. In larvae fat extract, it was found $22.22 \%$ oleic and $3.02 \%$ palmetoleic monounsaturated FAs, also $20.34 \%$ palmitic, $18.48 \%$ lauric, 5.59\% myristic, 5.34\% stearic mono saturated FAs with the similarity index 96\%, 97\%, 97\%, and 94\%, respectively. The poly saturated fatty acid (e.g., eicosanoic acid (arachidonic acid) and poly unsaturated fatty acids (e.g., cis, cis-9, 12-Octadecadienoic acid (Z, Z) (linoleic acid)) were present in trace amount, $0.36 \%$ and $0.23 \%$, respectively.

The more abundant amount of the saturated fatty acids compared to unsaturated identified in AWME was consistent with results published by Ushakova et al. [34]. They supposed that fatty acids in BSFL serve as energy storage. The amount of saturated fatty acids prevailed because these chemicals are less subjected to oxidation than unsaturated fatty acids. Our GC-MS analysis indicates the most abundant constituents of AWME, that confirmed the major FAs were saturated FAs and ordered in percentage scale, as shown in Table 4. Ewald et al. [35] reported, that from total amount of fatty acids in the larvae the major present filled up by lauric (C12:0), palmitic (C16:0) and oleic (C18:1 n-9) acids (52\%, 12-22\%, and 10-25\%, respectively). Our study revealed the much higher fatty acids profile and it was shown, based on our method of extraction, that we were able to extract from BSFL larvae fat $22.22 \%$ of the oleic (C18:1 n-9), 20.34\%, of palmitic (C16:0) and 18.48\% of lauric acid (C12:0) (Table 4). Although several reports [36-39] showed the different amount of lauric acid, palmitic and oleic acid, it is generally accepted that the variable percentages of FAs mainly depend on the sort of insects rearing substrate.

The increasing interest in the antimicrobial effects of FAs was mainly due to emergency of antibiotic resistance problem and urgent need to develop new classes of antibacterial agents that work against novel molecular targets [40]. Antimicrobial lipids, particularly single-chain amphiphilic lipids that destabilize bacterial cell membranes, are attractive candidates to become the next-generation antibacterial agents for the bacterial infections treatment. Phospholipids, as an example of amphiphilic molecules, are the main components of biological membranes. The amphiphilic nature of these molecules defines the way in which they form the cell membranes. They arrange themselves into bilayer, positioning their polar groups towards the surrounding aqueous medium, and their lipophilic chains towards the inside of the bilayer, defining a non-polar region between two polar ones. 
On the other hand, the awareness to reduce the use of the chemical pesticides by developing the alternative strategies or technologies to improve plant disease resistance and control of pathogens is highly promoted. There was growing interest in the research focused on the alternative pesticides and antimicrobial active compounds, including the plant extracts and essential oils of aromatic plants [41]. Under certain conditions, de novo mutations and selection can develop in pathogenic bacteria during one minute to hours, leading to the resistance genes arising, resulting in bacteria resistance to a single antibiotic [42]. Discovered FAs play a very crucial role in increasing resistance of plants to phytophathogens. Thus, linoleic acid found to induce systemic resistance of tobacco against the bacterial soft rot pathogen caused by Pectobacterium carotovorum subsp. carotovorum (Pcc) [43]. The lauric acid (LA) possessed the most potent activity to inhibit the growth of Gram-positive bacteria. Its monoglyceride derivative (glycerol monolaurate, (GML)) exhibited even more vigorous inhibitory activity than LA [44]. Importantly, both LA and GML are abundant in nature. They are recognized as safe by the Food and Drug Administration (FDA) in USA and exhibited full anti-infective applications, including several applications such as in agriculture [45]. The linoleic acids were phytotoxic and effective in inducing systemic resistance. In contrast, oleic acid was the least phytotoxic and caused no systemic resistance [46]. According to Blechert et al. [47], the octadecanoic acid (stearic acid) derivative, octadecatrienoic acid, $(Z, Z)$-methyl ester play an important role in plant defense mechanism. The plant contains linolec acid eliciting induced systemic resistance against phytopathogens. When a primary wound occurs in the plant, oligo-galacturonides signals formed, which activate octadecanoate to produce jasmonic acid, and which finally leads to the activation of the defense gene [48]. The hexadecanoic acid ethyl ester acts as antioxidant, nematicide, and pesticide. Furthermore, it may contribute to the antimicrobial and antioxidant activities [49]. As demonstrated in the present study, AWME of H. illucens larvae fat contains oleic, palmitic, lauric, myristic, stearic, and palmitoleic acid, which are saturated and unsaturated FAs having significant inhibition effect against bacteria that are in consistent with the activity of FAs, reported by other authors (Table 5).

Table 5. The content and published biological activity of major constituents of AWME of H. illucens larvae fat.

\begin{tabular}{|c|c|c|}
\hline Name of Compounds & Content $(\%)$ & Biological Activity \\
\hline Octadec-9-eonic acid (oleic acid) & 22.22 & Antibacterial [50] \\
\hline n-Hexadecanoic acid (palmitic acid) & 20.34 & Antimicrobial [51] \\
\hline Dodecanoic acid (lauric acid) & 18.48 & Antibacterial [52] \\
\hline Tetradecanoic acid (myristic acid) & 5.59 & Antibacterial [26] \\
\hline Octadecanoic acid (stearic acid) & 5.34 & Antimicrobial [53] \\
\hline cis-9-Hexadecenoic acid (palmitoleic acid) & 3.02 & Antibacterial [54] \\
\hline 1,2,3-Propantriol & 6.88 & Antimicrobial and antiseptic [55] \\
\hline Hexadecanoic acid, 2-hydroxy-1-(hydroxymethyl) ethyl ester & 0.51 & Antimicrobial [55] \\
\hline cis-9-Hexadecenal & 0.15 & Antimicrobial [55] \\
\hline $\begin{array}{l}\text { 9-Octadecenoic acid (Z)-, methyl } \\
\text { ester (oleic acid methyl ester) }\end{array}$ & 1.62 & Antimicrobial [56] \\
\hline $\begin{array}{c}\text { Dodecanoic acid, 2,3-dihydroxypropyl } \\
\text { ester (monolaurin) }\end{array}$ & 1.32 & Antimicrobial [57] \\
\hline Eicosanoic acid (arachidic acid) & 0.36 & $\begin{array}{l}\text { Antibacterial, antifungal, } \\
\text { antioxidant }[58,59]\end{array}$ \\
\hline $\begin{array}{l}\text { Hexadecanoic acid methyl ester } \\
\text { (palmitic acid methyl ester) }\end{array}$ & 0.35 & Antibacterial and antifungal [60] \\
\hline $\begin{array}{l}\text { Octadecanoic acid, methyl ester } \\
\text { (stearic acid methyl ester) }\end{array}$ & 0.34 & Antimicrobial [61] \\
\hline $\begin{array}{l}\text { 9,12-Octadecadienoic acid } \\
\quad(Z, Z) \text {-(linoleic acid) }\end{array}$ & 0.23 & Antibacterial [62] \\
\hline
\end{tabular}


FAs with the cis-form stereochemistry, mainly unsaturated fatty acids exhibit higher antibacterial activity than the corresponding trans-isomers [63]. Poly saturated FAs (eicosanoic acid) and poly unsaturated FAs such as 9, 12-Octadecadienoic acid (Z, Z)-(linoleic acid) possess a broad spectrum of antibacterial and antifungal effects $[58,59,62]$. Besides, the double bonds in free FAs typically have a cis-orientation showing the higher antibacterial activity than free FAs with double bonds in trans-orientation [64]. The esters of FAs, such as 9-octadecenoic acid (Z)-, methyl ester (oleic acid methyl ester), dodecanoic acid 2, 3-dihydroxypropyl ester (monolaurin), hexadecanoic acid 2-hydroxy-1-(hydroxymethyl) ethyl ester, hexadecanoic acid methyl ester (palmitic acid methyl ester) and octadecanoic acid methyl ester (stearic acid methyl ester), reported to have the sustain antibacterial effect-and even more effective than FAs [55-57,60,61].

In our study, the AWME from BSFL fat demonstrated antimicrobial efficacy against all five tested phytopathogens. The antibacterial effect against $X_{c c}$ measured by the diameter of the inhibition zone (IZD) and formed $19.5 \pm 0.28 \mathrm{~mm}$, MIC was $0.78 \mathrm{mg} / \mathrm{mL}$ (as indicated in Table 2 and Figure 2). The control bacteria exhibited a lag phase for $4 \mathrm{~h}$, and then $\mathrm{OD}_{600}$ values were rapidly increased. Nonetheless, the $\mathrm{OD}_{600}$ values of the AWME treatment groups showed a slight increase around $0.39 \mathrm{mg} / \mathrm{mL}$ of bacterial concentration during $4 \mathrm{~h}$, or $6 \mathrm{~h}$ of incubation within all range of added AWME at $0.78,1.56,3.13,6.25,12.5$, and $25 \mathrm{mg} / \mathrm{mL}$ (Figure 2). This finding is clear indication of AWME antibacterial activity against plant pathogenic bacteria, although we noted a slight difference in the ability to inhibit bacterial growth depending on the type of bacteria.

Of note, extracted antimicrobial peptides (AMPs) from BSFL showed IZD lower size (15.0 mm) and MIC higher $(50.0 \mathrm{mg} / \mathrm{mL})$ [16] in zone inhibition assay for Xcc during $24 \mathrm{~h}$ compared to our results of AWME antibacterial activity study. AMPs demonstrated an inhibitory effect against Gram-negative bacteria by IZD ranging from 9 to $13 \mathrm{~mm}$, and the $\mathrm{IC}_{50}$ also fluctuating between 33.47 to $39.28 \mathrm{mg} / \mathrm{mL}$ after $24 \mathrm{~h}$ of incubation [33]. Sledz et al. [22] demonstrated the MIC and MBC values of caffeine against Xcc, Dsol, Pcc and Pba in the range 1.74 to $3.66 \mathrm{mg} / \mathrm{mL}$ and 15 to $20 \mathrm{mg} / \mathrm{mL}$, respectively. Our data, in comparison to these results, indicated AWME from BSFL fat to be more effective against phytopathogenic bacteria in terms of IZD size in the range $12.5 \pm 0.7$ to $19.5 \pm 0.28 \mathrm{~mm}$, MIC in the range 0.87 to $1.56 \mathrm{mg} / \mathrm{mL}, \mathrm{MBC}$ in the range 0.78 to $1.56 \mathrm{mg} / \mathrm{mL}$ and $\mathrm{IC}_{50}$ in the range $366.8 \pm 0.38$ to $485.4 \pm 0.4 \mathrm{mg} / \mathrm{mL}$ after $24 \mathrm{~h}$ of incubation. Thus, while the AWME was more easily and more effectively isolated from BSFL fat, besides listed above superior antimicrobial characteristics, the AWME seems to be more effective than AMPs, and caffeine against actual phytopathogens.

Antibacterial efficacy of AWME was evaluated by disc assay, minimum inhibition concentration (MIC) and minimum bactericidal concentration (MBC) values. AWME showed high potency against phytopathogenic bacteria growth on both Mullar Hinton solid agar and in 96-well culture. The MBC value of AWME was determined by transferring $50 \mu \mathrm{L}$ aliquots from the 96-well plate with MIC bacterial suspension on the Petri dish agar. The MBC of AWME was $0.78 \mathrm{mg} / \mathrm{mL}$ for all tested strains except Pantoea agglomerans, which was inhibited and killed at $1.56 \mathrm{mg} / \mathrm{mL}$ of AWME after $48 \mathrm{~h}$ of incubation at $28{ }^{\circ} \mathrm{C}$ on petri dish plates. All the above-mentioned results prove the bactericidal capacity of AWME with high potency towards all tested phytopathogens. Of note, although the MICs of larval extract in our experiments $(0.78 \mathrm{mg} / \mathrm{mL} /$ well $)$ were higher than the MICs of standard antibiotic $(3.13 \mathrm{U} / \mathrm{mL}-6.25 \mu \mathrm{g} / \mathrm{mL} /$ well $)$, the $\mathrm{P} / \mathrm{S}$ antibiotic was composed of purified active ingredients, compared to the crude extracts of fly larvae [65]. Meziani et al. [66] reported that the $\mathrm{IC}_{50}$ for acetone extract of carob leaf was $1.5 \mathrm{mg} / \mathrm{mL}$ against Pectobacterium atrosepticum (Pba), while in our study $\mathrm{IC}_{50}$ for AWME was in the range $290.3 \pm 0.07$ to $400.2 \pm 0.35 \mu \mathrm{g} / \mathrm{mL}$ at $6 \mathrm{~h}$ and $24 \mathrm{~h}$ of incubation, respectively. Although MIC for lacaic acid-D- methyl ester, extracted from an Aloe vera, was $93.75 \mu \mathrm{g} / \mathrm{mL}$ against Xanthomonas campestris subsp. campestris (Xcc), but the MBC was $1.5 \mathrm{mg} / \mathrm{mL}$ and besides, it was not effective against Pectobacterium carotovorum subsp. Carotovorum (Pcc), compared to our findings [67]. Soberón et al. [68] declared that methanolic and the aqueous extract of Ligaria cuneifolia and Jodina rhombifolia leaf have the MICs ranging from 2.5 to $156 \mu \mathrm{g} / \mathrm{mL}$ and $5 \mathrm{mg} / \mathrm{mL}$, respectively, against Xcc, while these extracts were bacteriostatic. Hong et al. [69] found 
that phytochemicals extracted from Zingiber officinale rose have the MIC equal to $1.94 \mathrm{mg} / \mathrm{mL}$ against Pantoea agglomerans. In agreement with these data, the saturated and unsaturated fatty acids as major constituents of AWME from the $H$. illuscens larvae fat, possess the high antimicrobial effect against five important plant bacteria pathogens having $\mathrm{MIC}=0.78 \mathrm{mg} / \mathrm{mL}, \mathrm{MBC}=0.78-1.56 \mathrm{mg} / \mathrm{mL}$, and $\mathrm{IC}_{50}=366.8 \pm 0.38-485.4 \pm 0.4 \mathrm{mg} / \mathrm{mL}$.

The cell wall of Gram-positive bacteria consists only of a single thick peptidoglycan layer. In contrast, Gram-negative bacteria have a thin peptidoglycan layer. The lipoprotein, lipopolysaccharide, and phospholipids are forming their outer membrane layer. In this respect, the interaction of bacteria and fatty acids, the dominant constituents of the AWME of $H$. illucens larvae fat, can account for the differences in the susceptibility of Gram-positive and Gram- negative bacteria to larval extract. Such distinction may be associated with the inactivation of cell-signaling pathways, and/or degradation of an intracellular metabolic mechanism caused by the interaction of bacteria and fatty acids. Fatty acids have been reported to inhibit bacterial growth by disrupting bacterial membranes or inhibition of fatty acid synthesis [70]. Furthermore, the cis-bonds in unsaturated FAs cause a kink in the carbon chain that prevents these FAs from packing tightly into the membrane. Thus, when medium- and long-chains of unsaturated FAs are inserted into the membrane leading to the membrane's fluidity increase, they cause cell membrane instability and disruption development [71]. Zheng et al. [72] reported the inhibition of bacterial growth by long-chain unsaturated fatty acids (LCUFA) such as oleic acid, linoleic acid, palmitoleic acid, and arachidonic acid. The target for LCUFA was the bacterial enoyl-acyl carrier protein reductase (FabI), an essential component of bacterial fatty acids synthesis.

In our future study, we will focus on finding the mechanism of action of AWME against gram-negative and gram-positive bacteria. Besides, we plan to identify the active ingredients of AWME derived from $H$. illucens larvae fat and to develop their formulations suitable for practical use in agriculture.

\section{Conclusions}

In summary, the fatty acids and its derivatives of AWME of H. illucens larvae fat dose-dependently inhibited the growth and proliferation of plant pathogenic Gram-negative bacteria such as Xanthomonas campestris subsp. Campestris Pantoea agglomerans, Dickeya solani Pectobacterium carotovorum subsp. Carotovorum, and Pectobacterium atrosepticum. The present study also revealed the potential of H. illucens larvae fat to be used for future development of novel and effective natural disinfectant(s) and antibacterial agent(s). Our data indicate the perspectives of use the H. illucens larvae fat extract as a novel antibacterial agent candidate composition for agriculture crop protection.

Supplementary Materials: The following are available online at http://www.mdpi.com/2076-2607/8/9/1423/s1.

Author Contributions: H.M. performed the laboratory work, analyzed data, prepared the original draft; E.M. conceived, designed and supervised the study, wrote the article; Y.A. conduct GC-MS analysis; S.L. revised the manuscript, administrated project, procured the funding. All authors have read and agreed to the published version of the manuscript.

Funding: S.L., E.M. and H.M. acknowledge support by the Ministry of Education and Science of the Russian Federation (Agreement No. 02.A03.21.0003 dated August 28, 2013).

Acknowledgments: The authors would like to thank Denis Kuzmin, the Director of the School of Biological and Medical Physics at MIPT (Moscow, Russia) for project support. We also sincerely thank Gennady Ivanov, the Director of NordTechSad, LLC (Archangelsk, Russia) for the kind supply of the Hermetia illucens larvae fat, as well as Konstantin Miroshnikov, the Head of the Laboratory of molecular bioengineering, Institute of Bioorganic Chemistry RAS (Moscow, Russia) for providing of the plant bacteria stains.

Conflicts of Interest: The authors declare no conflict of interest. The funders had no role in the design of the study; in the collection, analysis, or interpretation of data; in the writing of manuscript, or in the decision to publish the results. 


\section{References}

1. Kannan, V.; Bastas, K.; Devi, R. Scientific and Economic Impact of Plant Pathogenic Bacteria. In Sustainable Approaches to Controlling Plant Pathogenic Bacteria; Kannan, V., Bastas, K., Devi, R., Eds.; CRC Press: Boca Raton, FL, USA, 2015; pp. 369-392.

2. Strange, R.N.; Scott, P.R. Plant Disease: A Threat to Global Food Security. Annu. Rev. Phytopathol. 2005, 43, 83-116. [CrossRef]

3. Czajkowski, R.; Pérombelon, M.C.M.; Jafra, S.; Lojkowska, E.; Potrykus, M.; Van Der Wolf, J.M.; Sledz, W. Detection, identification and differentiation of Pectobacterium and Dickeya species causing potato blackleg and tuber soft rot: A review. Ann. Appl. Biol. 2015, 166, 18-38. [CrossRef]

4. Pritchard, L.; Glover, R.H.; Humphris, S.; Elphinstone, J.G.; Toth, I.K. Genomics and taxonomy in diagnostics for food security: Soft-rotting enterobacterial plant pathogens. Anal. Methods 2016, 8, 12-24. [CrossRef]

5. Anajjar, B.; Aitmhand, R.; Timinouni, M.; Ennaji, M.M. Characterization by PCR of two strains of Erwinia carotovora isolated from the potato rhizosphere in the region of greater Casablanca Casablanca in Morocco. EPPO Bull. 2007, 37, 175-180. [CrossRef]

6. Cui, Y.; Chatterjee, A.; Yang, H.; Chatterjee, A.K. Regulatory network controlling extracellular proteins in Erwinia carotovora subsp. carotovora: FlhDC, the master regulator of flagellar genes, activates rsmB regulatory RNA production by affecting gacA and hexA (lrhA) expression. J. Bacteriol. 2008, 190, 4610-4623. [CrossRef] [PubMed]

7. Schwartz, A.R.; Potnis, N.; Timilsina, S.; Wilson, M.; Patané, J.; Martins, J.; Minsavage, G.V.; Dahlbeck, D.; Akhunova, A.; Almeida, N.; et al. Phylogenomics of Xanthomonas field strains infecting pepper and tomato reveals diversity in effector repertoires and identifies determinants of host specificity. Front. Microbiol. 2015, 6,1-17. [CrossRef]

8. Wulff, E.G.; Mguni, C.M.; Mortensen, C.N.; Keswani, C.L.; Hockenhull, J. Biological control of black rot (Xanthomonas campestris pv. campestris) of brassicas with an antagonistic strain of Bacillus subtilis in Zimbabwe. Eur. J. Plant Pathol. 2002, 108, 317-325. [CrossRef]

9. Motyka, A.; Zoledowska, S.; Sledz, W.; Lojkowska, E. Molecular methods as tools to control plant diseases caused by Dickeya and Pectobacterium spp: A minireview. New Biotechnol. 2017, 39, 181-189. [CrossRef] [PubMed]

10. Czajkowski, R.; Pérombelon, M.C.M.; Van Veen, J.A.; Van der Wolf, J.M. Control of blackleg and tuber soft rot of potato caused by Pectobacterium and Dickeya species: A review. Plant Pathol. 2011, 60, 999-1013. [CrossRef]

11. Zimnoch-Guzowska, E.; Lojkowska, M. Perombelon Resistance to Bacterial Pathogens. In Genetic Improvement of Solanaceous Crops Volume I: Potato; Razdan, M.K., Mattoo, A.K., Eds.; Science Publishers: Enfield, NH, USA, 2005; pp. 339-395.

12. Aćimović, S.G.; Zeng, Q.; McGhee, G.C.; Sundin, G.W.; Wise, J.C. Control of fire blight (Erwinia amylovora) on apple trees with trunk-injected plant resistance inducers and antibiotics and assessment of induction of pathogenesis-related protein genes. Front. Plant Sci. 2015, 6, 1-10. [CrossRef]

13. Hippler, F.W.R.; Boaretto, R.M.; Dovis, V.L.; Quaggio, J.A.; Azevedo, R.A.; Mattos-Jr, D. Oxidative stress induced by $\mathrm{Cu}$ nutritional disorders in Citrus depends on nitrogen and calcium availability. Sci. Rep. 2018, 8, 1-13. [CrossRef] [PubMed]

14. Purschke, B.; Scheibelberger, R.; Axmann, S.; Adler, A.; Jäger, H. Impact of substrate contamination with mycotoxins, heavy metals and pesticides on the growth performance and composition of black soldier fly larvae (Hermetia illucens) for use in the feed and food value chain. Food Addit. Contam. Part A Chem. Anal. Control. Expo. Risk Assess 2017, 34, 1410-1420. [CrossRef] [PubMed]

15. Makkar, H.P.S.; Tran, G.; Heuzé, V.; Ankers, P. State-of-the-art on use of insects as animal feed. Anim. Feed Sci. Technol. 2014, 197, 1-33. [CrossRef]

16. Park, K.H.; Kwak, K.W.; Nam, S.H.; Choi, J.Y.; Hyun, S.; Kim, H.G.; Kim, S.H. Antibacterial activity of larval extract from the black soldier fly Hermetia illucens (Diptera: Stratiomyidae) against plant pathogens. J. Entomol. Zool. Stud. 2015, 3, 176-179. [CrossRef]

17. Teh, C.H.; Nazni, W.A.; Lee, H.L.; Fairuz, A.; Tan, S.B.; Sofian-Azirun, M. In vitro antibacterial activity and physicochemical properties of a crude methanol extract of the larvae of the blow fly Lucilia cuprina. Med. Vet. Entomol. 2013, 27, 414-420. [CrossRef] [PubMed] 
18. Li, S.; Ji, H.; Zhang, B.; Tian, J.; Zhou, J.; Yu, H. Influence of black soldier fly (Hermetia illucens) larvae oil on growth performance, body composition, tissue fatty acid composition and lipid deposition in juvenile Jian carp (Cyprinus carpio var. Jian). Aquaculture 2016, 465, 43-52. [CrossRef]

19. Bauer, A.W.; Kirby, W.M.M.; Sherris, J.C.; Turck, M. Antibiotic Susceptibility Testing by a Standardized Single Disk Method. Am. J. Clin. Pathol. 1966, 45, 493-496. [CrossRef]

20. Thornsberry, C. Antimicrobial susceptibility testing: General considerations. In Manual of Clinical Microbiology, 5th ed.; BALOWS, A., Microbiology, A.S., Hausler, W.J., Jr., Herrmann, K.L., Isenberg, H.D., Shadomy, H.J., Eds.; American Society for Microbiology: Washington, DC, USA, 1991; pp. 1059-1201, ISBN 1555810292.

21. Ordóñez, R.M.; Zampini, I.C.; Moreno, M.I.N.; Isla, M.I. Potential application of Northern Argentine propolis to control some phytopathogenic bacteria. Microbiol. Res. 2011, 166, 578-584. [CrossRef]

22. Sledz, W.; Los, E.; Paczek, A.; Rischka, J.; Motyka, A.; Zoledowska, S.; Piosik, J.; Lojkowska, E. Antibacterial activity of caffeine against plant pathogenic bacteria. Acta Biochim. Pol. 2015, 62, 605-612. [CrossRef]

23. Scrimgeour, C. Chemistry of fatty acids. In Bailey's Industrial Oil and Fat Products; Shamsi, I.H., Shamsi, B.H., Jiang, L., Eds.; John Wiley and Sons, Inc.: New York, NY, USA, 2005; Volume 1, pp. 1-43.

24. Ramos-Bueno, R.P.; González-Fernández, M.J.; Sánchez-Muros-Lozano, M.J.; García-Barroso, F.; Guil-Guerrero, J.L. Fatty acid profiles and cholesterol content of seven insect species assessed by several extraction systems. Eur. Food Res. Technol. 2016, 242, 1471-1477. [CrossRef]

25. Caligiani, A.; Marseglia, A.; Sorci, A.; Bonzanini, F.; Lolli, V.; Maistrello, L.; Sforza, S. Influence of the killing method of the black soldier fly on its lipid composition. Food Res. Int. 2019, 116, 276-282. [CrossRef] [PubMed]

26. Agoramoorthy, G.; Chandrasekaran, M.; Venkatesalu, V.; Hsu, M.J. Antibacterial and antifungal activities of fatty acid methyl esters of the blind-your-eye mangrove from India. Braz. J. Microbiol. 2007, 38, 739-742. [CrossRef]

27. Sivakumar, R.; Jebanesan, A.; Govindarajan, M.; Rajasekar, P. Larvicidal and repellent activity of tetradecanoic acid against Aedes aegypti (Linn.) and Culex quinquefasciatus (Say.) (Diptera:Culicidae). Asian Pac. J. Trop. Med. 2011, 4, 706-710. [CrossRef]

28. Choi, W.H.; Jiang, M. Evaluation of antibacterial activity of hexanedioic acid isolated from Hermetia illucens larvae. J. Appl. Biomed. 2014, 12, 179-189. [CrossRef]

29. Kim, S.A.; Rhee, M.S. Highly enhanced bactericidal effects of medium chain fatty acids (caprylic, capric, and lauric acid) combined with edible plant essential oils (carvacrol, eugenol, b-resorcylic acid, trans-cinnamaldehyde, thymol, and vanillin) against Escherichia coli O15. Food Control 2016, 60, 447-454. [CrossRef]

30. Sugumaran, M. Comparative Biochemistry of Eumelanogenesis and the Protective Roles of Phenoloxidase and Melanin in Insects. Pigment Cell Res. 2002, 15, 2-9. [CrossRef] [PubMed]

31. Park, K.H.; Zeon, S.-R.; Lee, J.-G.; Choi, S.-H.; Shin, Y.K.; Park, K.-I. In vitro and in vivo efficacy of drugs against the protozoan parasite Azumiobodo hoyamushi that causes soft tunic syndrome in the edible ascidian Halocynthia roretzi (Drasche). J. Fish Dis. 2014, 37, 309-317. [CrossRef] [PubMed]

32. Soetemans, L.; Uyttebroek, M.; D'Hondt, E.; Bastiaens, L. Use of organic acids to improve fractionation of the black soldier fly larvae juice into lipid- and protein-enriched fractions. Eur. Food Res. Technol. 2019, 245, 2257-2267. [CrossRef]

33. Choi, W.H.; Yun, J.H.; Chu, J.P.; Chu, K.B. Antibacterial effect of extracts of hermetia illucens (diptera: Stratiomyidae) larvae against gram-negative bacteria. Entomol. Res. 2012, 42, 219-226. [CrossRef]

34. Ushakova, N.A.; Brodskii, E.S.; Kovalenko, A.A.; Bastrakov, A.I.; Kozlova, A.A.; Pavlov, D.S. Characteristics of lipid fractions of larvae of the black soldier fly Hermetia illucens. Dokl. Biochem. Biophys. 2016, 468, 209-212. [CrossRef]

35. Ewald, N.; Vidakovic, A.; Langeland, M.; Kiessling, A.; Sampels, S.; Lalander, C. Fatty acid composition of black soldier fly larvae (Hermetia illucens)_Possibilities and limitations for modification through diet. Waste Manag. 2020, 102, 40-47. [CrossRef] [PubMed]

36. Barroso, F.G.; Sánchez-Muros, M.J.; Segura, M.; Morote, E.; Torres, A.; Ramos, R.; Guil, J.L. Insects as food: Enrichment of larvae of Hermetia illucens with omega 3 fatty acids by means of dietary modifications. J. Food Compos. Anal. 2017, 62, 8-13. [CrossRef] 
37. Liland, N.S.; Biancarosa, I.; Araujo, P.; Biemans, D.; Bruckner, C.G.; Waagbø, R.; Torstensen, B.E.; Lock, E.-J.J. Modulation of nutrient composition of black soldier fly (Hermetia illucens) larvae by feeding seaweed-enriched media. PLoS ONE 2017, 12, 3188. [CrossRef] [PubMed]

38. Meneguz, M.; Schiavone, A.; Gai, F.; Dama, A.; Lussiana, C.; Renna, M.; Gasco, L. Effect of rearing substrate on growth performance, waste reduction efficiency and chemical composition of black soldier fly (Hermetia illucens) larvae. J. Sci. Food Agric. 2018, 98, 5776-5784. [CrossRef]

39. Spranghers, T.; Ottoboni, M.; Klootwijk, C.; Ovyn, A.; Deboosere, S.; De Meulenaer, B.; Michiels, J.; Eeckhout, M.; De Clercq, P.; De Smet, S. Nutritional composition of black soldier fly (Hermetia illucens) prepupae reared on different organic waste substrates. J. Sci. Food Agric. 2017, 97, 2594-2600. [CrossRef]

40. Alanis, A.J. Resistance to antibiotics: Are we in the post-antibiotic era? Arch. Med. Res. 2005, 36, $697-705$. [CrossRef]

41. Kotan, R.; Cakir, A.; Dadasoglu, F.; Aydin, T.; Cakmakci, R.; Ozer, H.; Kordali, S.; Mete, E.; Dikbas, N. Antibacterial activities of essential oils and extracts of Turkish Achillea, Satureja and Thymus species against plant pathogenic bacteria. J. Sci. Food Agric. 2010, 90, 145-160. [CrossRef]

42. Shea, K.M. Antibiotic resistance: What is the impact of agricultural uses of antibiotics on children's health? Pediatrics 2003, 112, 253-258.

43. Sumayo, M.S.; Kwon, D.K.; Ghim, S.Y. Linoleic acid-induced expression of defense genes and enzymes in tobacco. J. Plant Physiol. 2014, 171, 1757-1762. [CrossRef]

44. Schlievert, P.M.; Peterson, M.L. Glycerol Monolaurate Antibacterial Activity in Broth and Biofilm Cultures. PLoS ONE 2012, 7, 350. [CrossRef]

45. Skřivanová, E.; Molatová, Z.; Marounek, M. Effects of caprylic acid and triacylglycerols of both caprylic and capric acid in rabbits experimentally infected with enteropathogenic Escherichia coli O103. Vet. Microbiol. 2008, 126, 372-376. [CrossRef] [PubMed]

46. Cohen, Y.; Gisi, U.; Mosinger, E. Systemic resistance of potato plants against Phytophthora infestans induced by unsaturated fatty acids. Physiol. Mol. Plant Pathol. 1991, 38, 255-263. [CrossRef]

47. Blechert, S.; Brodschelm, W.; Hölder, S.; Kammerer, L.; Kutchan, T.M.; Mueller, M.J.; Xia, Z.Q.; Zenk, M.H. The octadecanoic pathway: Signal molecules for the regulation of secondary pathways. Proc. Natl. Acad. Sci. USA 1995, 92, 4099-4105. [CrossRef]

48. Farmer, E.E.; Ryan, C.A. Octadecanoid Precursors of Jasmonic Acid Activate the Synthesis of Wound-Inducible Proteinase Inhibitors. Plant Cell 1992, 4, 129-134. [CrossRef] [PubMed]

49. Kumar, P.P.; Kumaravel, S.; Lalitha, C. Screening of antioxidant activity, total phenolics and GC-MS study of Vitex negundo. Afr. J. Biochem. Res. 2010, 4, 191-195.

50. Awa, E.P.; Ibrahim, S.; Ameh, D.A. GC/MS Analysis and Antimicrobial activity of Diethyl ether fraction of Methanoolic extract from the Stem Bark of Annona senegalensis Pers. Int. J. Pharm. Sci. Res. 2012, 3, 4213-4218. [CrossRef]

51. Ouattara, B.; Simard, R.E.; Holley, R.A.; Piette, G.J.P.; Bégin, A. Antibacterial activity of selected fatty acids and essential oils against six meat spoilage organisms. Int. J. Food Microbiol. 1997, 37, 155-162. [CrossRef]

52. Nair, R.R. Agnihotra Yajna: A Prototype of South Asian Traditional Medical Knowledge. JAMS J. Acupunct. Meridian Stud. 2017, 10, 143-150. [CrossRef]

53. Rahuman, A.A.; Gopalakrishnan, G.; Ghouse, B.S.; Arumugam, S.; Himalayan, B. Effect of Feronia limonia on mosquito larvae. Fitoterapia 2000, 71, 553-555. [CrossRef]

54. Khalil, A.S.; Rahim, A.A.; Taha, K.K.; Abdallah, K.B. Characterization of Methanolic Extracts of Agarwood Leaves. J. Appl. Ind. Sci. 2013, 1, 78-88.

55. Duke, J.A. Handbook of Biologically Active Phytochemicals and Their Activities; CRC Press, Inc.: Boca Raton, FL, USA, 1992; ISBN 9780849336706.

56. Chandrasekaran, M.; Kannathasan, K.; Venkatesalu, V. Antimicrobial activity of fatty acid methyl esters of some members of chenopodiaceae. Z. Naturforsch. Sect. C J. Biosci. 2008, 63, 331-336. [CrossRef] [PubMed]

57. Enig, M.G. Lauric oils as antimicrobial agents: Theory of effect, scientific rationale, and dietary application as adjunct nutritional support for HIV-infected individuals. In Nutrients and Foods in AIDS; Watson, R.R., Ed.; AI12/3/04; CRC Press: Boca Raton, FL, USA, 1998; pp. 81-97. [CrossRef]

58. Pinto, M.E.A.; Araújo, S.G.; Morais, M.I.; Sá, N.P.; Lima, C.M.; Rosa, C.A.; Siqueira, E.P.; Johann, S.; Lima, L.A.R.S. Antifungal and antioxidant activity of fatty acid methyl esters from vegetable oils. An. Acad. Bras. Cienc. 2017, 89, 1671-1681. [CrossRef] 
59. Sahin, N.; Kula, I.; Erdogan, Y. Investigation of antimicrobial activities of nonanoic acid derivatives. Fresenius Environ. Bull. 2006, 15, 141-143.

60. Chandrasekaran, M.; Senthilkumar, A.; Venkatesalu, V. Antibacterial and antifungal efficacy of fatty acid methyl esters from the leaves of Sesuvium portulacastrum L. Eur. Rev. Med. Pharmacol. Sci. 2011, 15, 775-780. [PubMed]

61. Abou-Elela, G.M.; Abd-Elnaby, H.; Ibrahim, H.A.H.; Okbah, M.A. Marine Natural Products and Their Potential Applications as Anti-Infective Agents. World Appl. Sci. J. 2009, 7, 872-880.

62. McGaw, L.J.; Jäger, A.K.; Van Staden, J. Antibacterial effects of fatty acids and related compounds from plants. S. Afr. J. Bot. 2002, 68, 417-423. [CrossRef]

63. Kabara, J.J.; Scherr, G.H. Advances in Human Nutrition; Scherr, G.H., Ed.; Chem-Orbital: Park Forest, IL, USA, 1986; ISBN 0930376390.

64. Feldlaufer, M.F.; Knox, D.A.; Lusby, W.R.; Shimanuki, H. Antimicrobial activity of fatty acids against Bacillus larvae, the causative agent of American foulbrood disease. Apidologie 1993, 24, 95-99. [CrossRef]

65. Teh, C.H.; Nazni, W.A.; Nurulhusna, A.H.; Norazah, A.; Lee, H.L. Determination of antibacterial activity and minimum inhibitory concentration of larval extract of fly via resazurin-based turbidometric assay. BMC Microbiol. 2017, 17, 36. [CrossRef]

66. Meziani, S.; Oomah, B.D.; Zaidi, F.; Simon-Levert, A.; Bertrand, C.; Zaidi-Yahiaoui, R. Antibacterial activity of carob (Ceratonia siliqua L.) extracts against phytopathogenic bacteria Pectobacterium atrosepticum. Microb. Pathog. 2015, 78, 95-102. [CrossRef]

67. Canche-Escamilla, G.; Colli-Acevedo, P.; Borges-Argaez, R.; Quintana-Owen, P.; May-Crespo, J.F.; Cáceres-Farfan, M.; Yam Puc, J.A.; Sansores-Peraza, P.; Vera-Ku, B.M. Extraction of phenolic components from an Aloe vera (Aloe barbadensis Miller) crop and their potential as antimicrobials and textile dyes. Sustain. Chem. Pharm. 2019, 14, 1-8. [CrossRef]

68. Soberón, J.R.; Sgariglia, M.A.; Dip Maderuelo, M.R.; Andina, M.L.; Sampietro, D.A.; Vattuone, M.A. Antibacterial activities of Ligaria cuneifolia and Jodina rhombifolia leaf extracts against phytopathogenic and clinical bacteria. J. Biosci. Bioeng. 2014, 118, 599-605. [CrossRef] [PubMed]

69. Hong, H.; Lee, J.H.; Kim, S.K. Phytochemicals and antioxidant capacity of some tropical edible plants. Asian Australas. J. Anim. Sci. 2018, 31, 1677-1684. [CrossRef] [PubMed]

70. Halldor, T. Hilmarsson Hilmar Antimicrobial Lipids as Disinfectants, Antiseptics and Sanitizers. In Lipids and Essential Oils as Antimicrobial Agents; Thormar, H., Ed.; John Wiley \& Sons Ltd.: West Sussex, UK, 2011; pp. 179-201.

71. Stulnig, T.M.; Huber, J.; Leitinger, N.; Imre, E.M.; Angelisová, P.; Nowotny, P.; Waldhäusl, W. Polyunsaturated Eicosapentaenoic Acid Displaces Proteins from Membrane Rafts by Altering Raft Lipid Composition. J. Biol. Chem. 2001, 276, 37335-37340. [CrossRef] [PubMed]

72. Zheng, C.J.; Yoo, J.S.; Lee, T.G.; Cho, H.Y.; Kim, Y.H.; Kim, W.G. Fatty acid synthesis is a target for antibacterial activity of unsaturated fatty acids. FEBS Lett. 2005, 579, 5157-5162. [CrossRef]

(C) 2020 by the authors. Licensee MDPI, Basel, Switzerland. This article is an open access article distributed under the terms and conditions of the Creative Commons Attribution (CC BY) license (http://creativecommons.org/licenses/by/4.0/). 